\title{
Challenges of Smallholder Farming in Ethiopia and Opportunities by Adopting Climate-Smart Agriculture
}

\author{
Gebeyanesh Zerssa ${ }^{1,2}\left(\mathbb{D}\right.$, Debela Feyssa ${ }^{2,+}$, Dong-Gill Kim ${ }^{3}$ and Bettina Eichler-Löbermann ${ }^{1, * \mathbb{D}}$ \\ 1 Department of Agronomy and Crop Science, Faculty of Agricultural and Environmental Sciences, \\ University of Rostock, P.O. Box 18059 Rostock, Germany; workugb2010@gmail.com \\ 2 Department of Natural Resources Management, College of Agriculture and Veterinary Medicine, \\ Jimma University, P.O. Box 307 Jimma, Ethiopia; feyssahunde@yahoo.com \\ 3 Wondo Genet College of Forestry and Natural Resources, Hawassa University, P.O. Box 128 Shshemene, \\ Ethiopia; donggillkim@gmail.com \\ * Correspondence: bettina.eichler@uni-rostock.de \\ + Deceased.
}

check for updates

Citation: Zerssa, G.; Feyssa, D.; Kim, D.-G.; Eichler-Löbermann, B. Challenges of Smallholder Farming in Ethiopia and Opportunities by Adopting Climate-Smart Agriculture. Agriculture 2021, 11, 192. https:/ doi. org/10.3390/agriculture11030192

Academic Editor: Jonas Jägermeyr

Received: 20 January 2021

Accepted: 24 February 2021

Published: 26 February 2021

Publisher's Note: MDPI stays neutral with regard to jurisdictional claims in published maps and institutional affiliations.

Copyright: (c) 2021 by the authors. Licensee MDPI, Basel, Switzerland. This article is an open access article distributed under the terms and conditions of the Creative Commons Attribution (CC BY) license (https:// creativecommons.org/licenses/by/ $4.0 /)$.

\begin{abstract}
Agriculture is the backbone of the Ethiopian economy, and the agricultural sector is dominated by smallholder farming systems. The farming systems are facing constraints such as small land size, lack of resources, and increasing degradation of soil quality that hamper sustainable crop production and food security. The effects of climate change (e.g., frequent occurrence of extreme weather events) exacerbate these problems. Applying appropriate technologies like climate-smart agriculture (CSA) can help to resolve the constraints of smallholder farming systems. This paper provides a comprehensive overview regarding opportunities and challenges of traditional and newly developed CSA practices in Ethiopia, such as integrated soil fertility management, water harvesting, and agroforestry. These practices are commonly related to drought resilience, stability of crop yields, carbon sequestration, greenhouse gas mitigation, and higher household income. However, the adoption of the practices by smallholder farmers is often limited, mainly due to shortage of cropland, land tenure issues, lack of adequate knowledge about CSA, slow return on investments, and insufficient policy and implementation schemes. It is suggested that additional measures be developed and made available to help CSA practices become more prevalent in smallholder farming systems. The measures should include the utilization of degraded and marginal lands, improvement of the soil organic matter management, provision of capacity-building opportunities and financial support, as well as the development of specific policies for smallholder farming.
\end{abstract}

Keywords: food security; soil fertility; agroforestry; organic matter; greenhouse gas; agronomy; water harvesting

\section{Introduction}

Agriculture is the backbone of the Ethiopian economy and it contributes about $50 \%$ of the country's gross domestic product (GDP) and more than $80 \%$ of its exports [1,2]. Furthermore, it is one of the main employment sectors with about $80 \%$ of the country's population depending on the agricultural sector for their livelihoods [3]. The agricultural sector of Ethiopia is dominated by smallholder farming [4]. Smallholder farms are defined as being smaller than 2 ha and are mainly managed with family labor [5]. In Ethiopia, about $95 \%$ of main crops (e.g., cereals, pulses, oilseeds, vegetables, root crops, fruits, and cash crops) are produced by smallholder farms [4]. However, these farms are facing various constraints that hamper crop productivity. Major constraints include poor soil fertility, severe land degradation, high dependence on rainfall, low availability and poor quality of seeds and fertilizers, economic constraints like low income and lack of financial support, as well as insufficient policies and guidelines $[3,6,7]$. Weather phenomena related to climate change like severe drought and heavy rainfall also affect the agricultural sector. 
Smallholder farmers with limited resources have particular difficulties overcoming these obstacles $[4,8]$. These problems are exacerbated by the rapid population growth and environmental degradation. Consequently, appropriate management practices are urgently needed to resolve the constraints and to increase crop production without altering its potential for future generations [9].

Climate-smart agriculture (CSA) is an agricultural approach that aims to increase agricultural productivity under the new realities of climate change. This includes increasing soil fertility and carbon sequestration, reducing greenhouse gas (GHG) emissions, enhancing resilience to climate change, and a stronger use of natural ecosystem services [10-14]. Managing CSA includes various practices such as mulching, the application of organic materials, intercropping, conservation tillage, crop rotation, integrated nutrient management, water harvesting, and agroforestry [15-17].

Globally, CSA has been recognized as a suitable solution to overcome the challenges of food security and climate change impacts on agriculture especially in vulnerable areas [17]. Thus, the adoption of CSA practices could help smallholder farming in Ethiopia to enhance food security and appropriately manage climate change impacts [18-21]. However, despite these potential benefits CSA is only practiced in some areas of Ethiopia and has not been sufficiently adopted by smallholder farmers [14,22]. This is partly attributed to available labor, knowledge, and level of education $[4,23,24]$, but a shortage of funds as well as policy constraints are further important aspects [6]. Although Ethiopia's agriculture has enjoyed increasing governmental support over the years [25], especially land tenure policy and financial and price support schemes are described as being insufficient or ineffective. This results in an underutilization of techniques for soil and water conservation and hinders the adoption of CSA in Ethiopia $[21,25,26]$. While many CSA practices are relatively low-cost, they may not be affordable for farmers, who suffer from price distortions, limited land, and low productivity [21,27]. CSA practices can also result in an increased workload. This was for instance shown for conservation tillage, which is often related to a higher occurrence of weeds and may increase the work burden on women, who are usually responsible for manual weeding [28]. Therefore, relevant stakeholders must clearly know the impacts of CSA practices and must also assess their costs and benefits under the respective conditions in order to make decisions on promoting one practice versus another [29].

Holistic approaches are needed as a basis for appropriate future strategies towards sustainable agriculture and rural welfare, as recently suggested for sub-Saharan Africa by Stewart et al. [30] and more specifically for Ethiopia by Amare et al. [31]. Various studies have shown, that CSA approaches exist which have the potential to enhance resilience to climate change and to achieve more sustainability for smallholder farming in Ethiopia $[4,23,32]$. However, the studies often narrowly focus on individual CSA practices under specific circumstances. An integrative and systematic analysis considering environmental and socioeconomic conditions as well as agricultural policies on potentials and challenges of adopting CSA in Ethiopian smallholder faming systems has not yet been undertaken. The consideration of interlinking influencing factors in our review resulted in four main objectives: (I) to summarize the current situation in smallholder farming in Ethiopia, (II) to explore potential CSA practices for a sustainable improvement of agro ecosystems, (III) to identify relevant obstacles that hinder the application of CSA practices in smallholder farming systems, and (IV) to suggest opportunities and solutions to sustainably develop smallholder farming systems and to empower smallholder farmers to adopt CSA practices.

To provide relevant information on (I) conditions in smallholder farming, (II) sustainable and climate-smart agriculture, and (III) agricultural policy and socio-economic issues and to achieve the aims of this review, a comprehensive analysis of articles in the Web of Science and Google Scholar was done using the following terms: "climate-smart agriculture", or "smallholder farming", or "integrated nutrient management", or "soil fertility", or "sustainable agriculture", or "agroforestry", or "conservation agriculture", or "agricultural policy", or "socio-economic effects" and/or "Ethiopia". These terms are commonly used in 
agricultural research with a focus on climate change adaptations and mitigation and they cover the main research outputs about the current status of CSA in Ethiopia. Moreover, the terms include the concepts of CSA pillars (adaptations, productivity, and mitigations). For our study, we mainly focused on developments during the last two decades, when measures to mitigate the impacts of climate change became more relevant.

\section{Current Status of Smallholder Farming in Ethiopia}

\subsection{Agricultural Productivity}

In Ethiopia, about $60 \%$ of farmers cultivate less than 0.90 ha in very fragmented landscapes $[5,20,33]$. However, smallholder farming is responsible for a large proportion of Ethiopian food production. It cultivates more than $90 \%$ of the total cropland and provides more than $90 \%$ of agricultural output $[4,34,35]$. Smallholder farmers commonly cultivate cereals such as teff (Eragrostis tef [Zucc.] Trotter), maize (Zea mays), wheat (Triticum aestivum), barley (Hordeum vulgare), and sorghum (Sorghum bicolor) [36,37] (Figure 1). Crop yields in the smallholder farms are very low compared to their potential capacity [36,38] and are also substantially lower (less than $50 \%$ ) than the yields obtained in experimental farms and research stations (Figure 2). The gap is especially remarkable for maize, with an average yield of $2.6 \mathrm{tha}^{-1}$ compared with the potential yield of $7.8 \mathrm{tha}^{-1}$ obtained in on-farm trials $[36,37,39]$. The low crop yields affects food security, with a large amount of grain needing to be imported [40,41]. For instance, 30 to $50 \%$ of domestically consumed wheat was imported in the past, due to a lack of production inside the country [40,41].

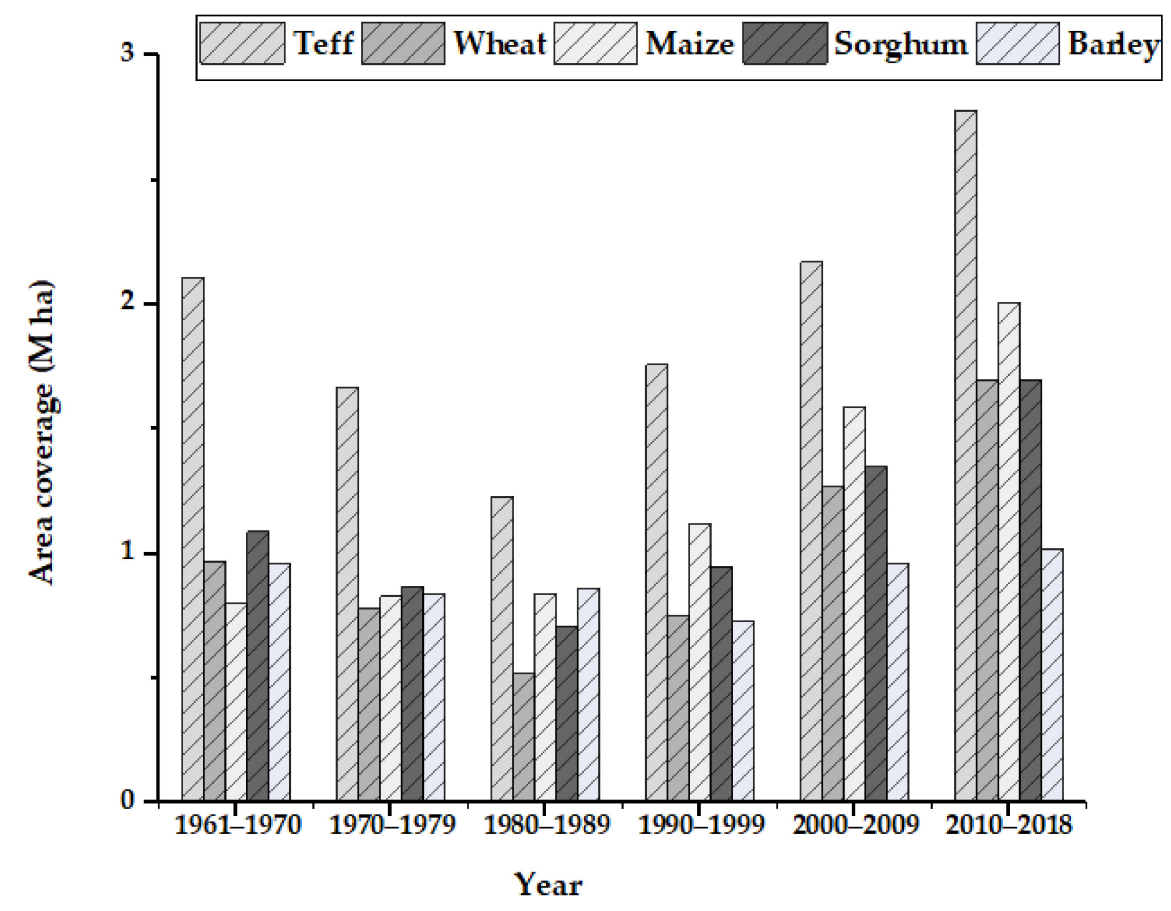

Figure 1. Variation of area coverage of major cereal crops (teff, wheat, maize, sorghum, and barley) in Ethiopia from 1961 to 2018. Source: Taffesse et al., CSA [27,28]. 


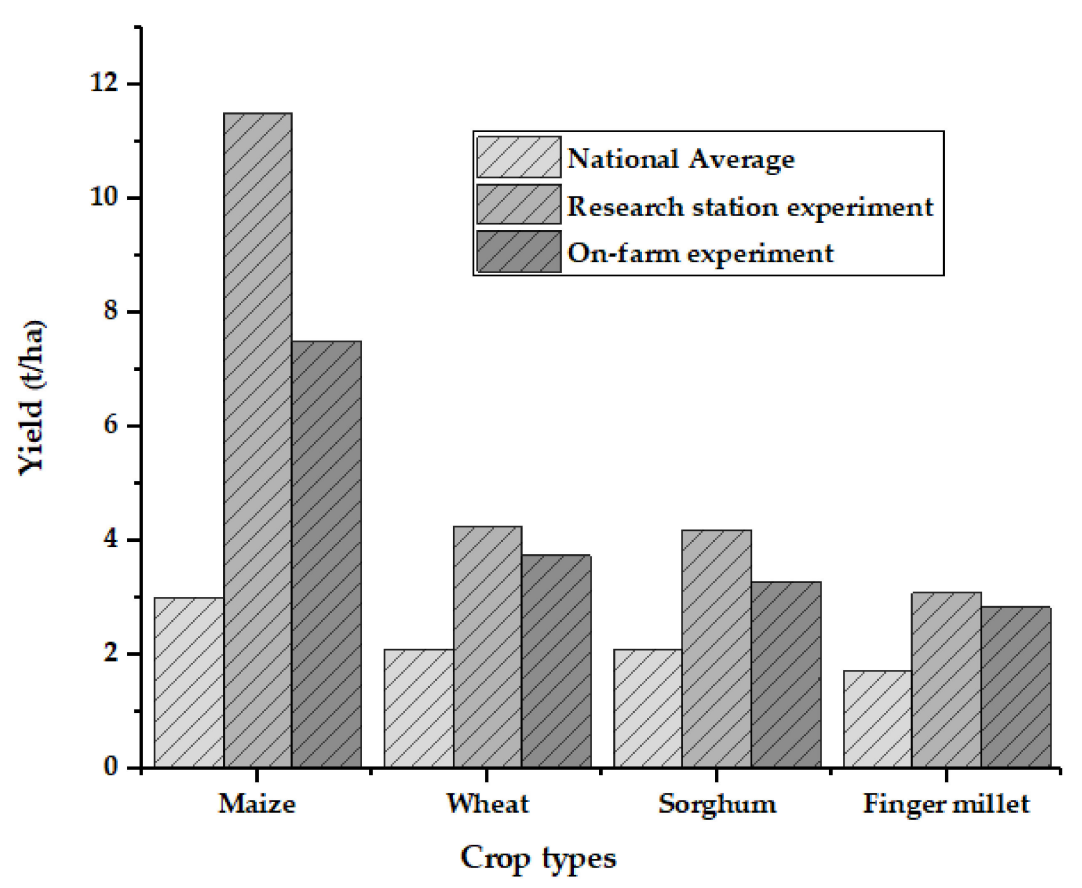

Figure 2. Average of crop yields (t/ha) (1995-2018) compared to the yields from research stations and on-farm experiments in Ethiopia. Source: Taffesse et al., CSA, Marloes et al. [27-29].

Ethiopia has a large livestock resource with about 60 million heads of cattle and about 61 million sheep and goats [42]. The animals belong to various production systems ranging from pastoral to mixed crop-livestock systems with different levels of intensification [24,42]. About $75 \%$ of livestock is concentrated in the highlands of Ethiopia. The animals play a critical role in the mixed smallholder farming systems (i.e., livestock and crop production within the same farm unit) as they diversify income sources for smallholder farmers, provide manure as a source of fertilizer, increase the availability of animal traction, and can act as buffer against adverse weather patterns for cropping [43-45]. It has also been shown that livestock ownership can increase the probability of adopting sustainable farming methods in Ethiopian highlands [21].

However, in the face of decreasing grazing lands and high prices for animal feed animal husbandry competes with crop farming for limited resources [43,46-48]. Despite the limited space for the cultivation of fodder crops, the feeding of crop residues is also problematic, as this material is urgently needed to maintain the fertility of soils [46]. High livestock densities may reduce the quality of soils and overgrazing often exposes agricultural lands to erosion and structure deterioration [49-52]. Understanding the tradeoffs between number of livestock, total farm size, and sustainable land production is therefore very important [43].

In Ethiopia about $40 \%$ of agricultural land is already affected by land degradation resulting in decreased agricultural productivity [53]. In particular, the densely populated highlands of Ethiopia have been experiencing losses in soil fertility for the last three decades $[44,50,54]$. This is not only related to high livestock densities, but also to improper land management (i.e., tilling steep slopes), an intensive use of water, and the discharge of agrochemicals $[53,55]$.

\subsection{Agricultural Land Size}

The amount of land dedicated to agriculture has been steadily increasing since 1980 [56]. From 2000 to 2008, croplands were expanded by about 4 million ha, and $80 \%$ of this expansion occurred through the conversion of forest land, woodland, and shrub land [57]. Deforestation for the expansion of agricultural land in Ethiopia increased $\mathrm{CO}_{2}$ emissions from 5.1 Mt in 2005 to $6.5 \mathrm{Mt}$ in 2010 [58]. Although the expansion of cropland 
has slowed down in recent years, the amount of agricultural land still increases by about $1.5 \%$ every year [56]. In spite of the expansion of cropland, due to the quickly growing population in the rural parts of Ethiopia, the size of cropland per capita has been decreasing drastically [35,59] (Figure 3). Consequently, most Ethiopian farmers are still smallholder farmers. Farm size is usually negatively correlated with population density. For example, the average farm size of less populated areas like Oromia (average farm size: $1.15 \mathrm{ha}$ ) and Amhara (1.09 ha) is larger than that of the densely populated Southern Nations, Nationalities, and Peoples' Region (SNNPR) (0.49 ha) [36]. It has been predicted that smallholder farming systems will continue to dominate the agriculture sector and that average farm sizes will continue to decline, since the further expansion of cropland will become more difficult, while the population will continue to increase $[20,60,61]$.

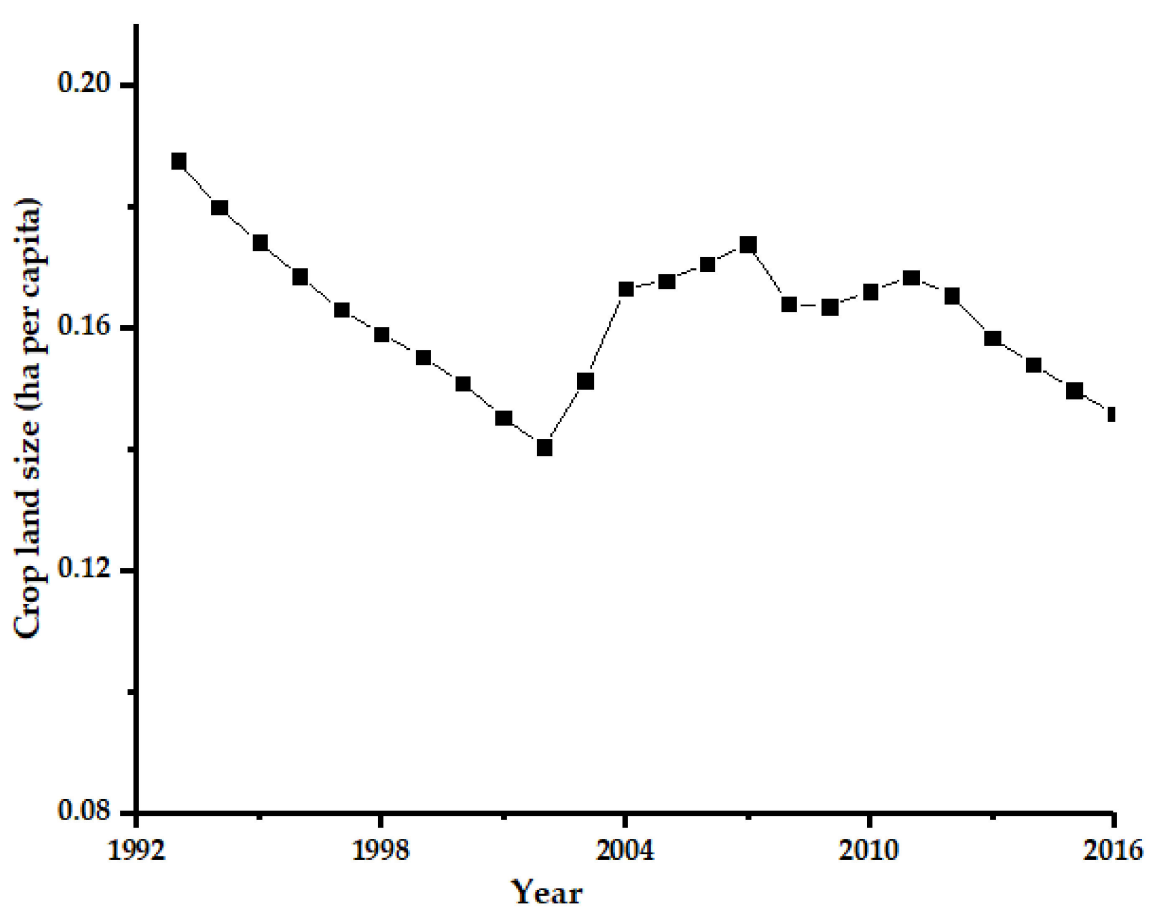

Figure 3. Development of cropland area (ha per capita) in Ethiopia from 1993 to 2016. Source: MoARD, Taffesse et al., CSA $[27,28,36]$.

\subsection{Fertilizer Application and Organic Matter Management}

For smallholder farmers, the use of fertilizers is often unaffordable resulting in negative nutrient balances in croplands. Inorganic fertilizer consumption, nonetheless, increased between 1961 and 2016 (Figure 4). For more than four decades until 2016, urea and diammonium phosphate (DAP) were the only commercial fertilizers used in Ethiopian agriculture [39,62]. Nowadays DAP is being gradually substituted by a combination fertilizer based on nitrogen $(\mathrm{N})$, phosphorus $(\mathrm{P})$, and sulfur $(\mathrm{S})$ in order to meet the $\mathrm{S}$ demand of Ethiopian soils [62,63]. The current application rate of inorganic fertilizer is around $40 \mathrm{~kg} \mathrm{ha}^{-1}$ [62], which is much lower than in many other countries [64]. A further problem is the substantial imbalance between the nutrients applied, which results in lower nutrient efficiency [65]. For instance, in the Central Highlands, $\mathrm{N}$ and potassium (K) fluxes were negative in teff-based systems $\left(-28 \mathrm{~kg} \mathrm{~N} \mathrm{ha}^{-1} \mathrm{a}^{-1}\right.$ and $\left.-34 \mathrm{~kg} \mathrm{~K} \mathrm{ha}^{-1} \mathrm{yr}^{-1}\right)$ and in enset-based systems (Ensete ventricosum (Welw.) Cheesman) ( $-6 \mathrm{~kg} \mathrm{~N} \mathrm{ha}^{-1} \mathrm{a}^{-1}$ and $-14 \mathrm{~kg} \mathrm{~K} \mathrm{ha}^{-1} \mathrm{a}^{-1}$ ), while $\mathrm{P}$ balances were almost neutral or slightly positive [66]. 


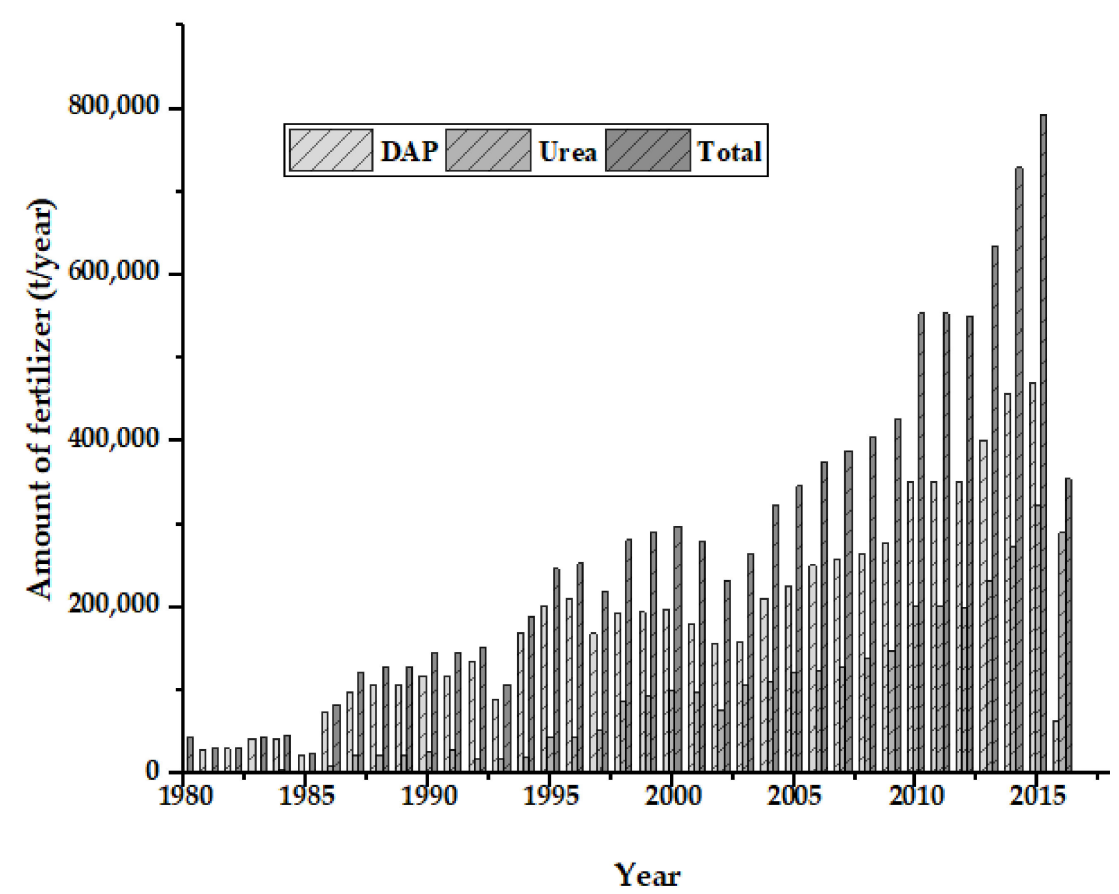

Figure 4. Development of annual urea and di-ammonium phosphate (DAP) fertilizer consumption (t/year) in Ethiopia from 1980 to 2016. Source: CSA, Abraha et al. [30,47].

Despite many positive effects on soil quality, the application of organic fertilizers is limited in smallholder farms, since the majority of available organic matter is used as fuel, animal feed, and construction material $[16,67,68]$. Ethiopia has a large number of livestock and animal manure should be widely available $[45,69]$. However, because of its use as a rural energy source, the bulkiness of the material, and lack of transport, manure is only spread on a small part of the agricultural area, mainly restricted to home gardens [24,70]. Additionally, out of $22.4 \mathrm{Mt}$ of crop residues annually available in Ethiopia, about 10.3 Mt are used as fuel [47]. With the removal of crop residues from fields, the nutrient balances turn further negative [71]. The use of cover crops is also very limited, because of the low availability of fields not used for food crops [16,68]. It has been shown that the application of organic fertilization to fields increases when the prices for chemical fertilizers increase [72]. However, as long as organic materials are lacking, organic matter management will remain of little importance [73].

\subsection{Water Availability}

The vast majority of Ethiopian farms rely on rainfall [7]. Irregular rainfall patterns have often resulted in low agricultural productivity and food insecurity. The increasing occurrence of extreme weather events (e.g., severe droughts and heavy rainfalls) is a further threat to smallholder farms [74,75]. Intensive rainfall often results in surface runoff combined with losses of the fertile soil from the upper soil layer. Lack of rain over long periods combined with high temperatures cause serious deficits in soil moisture [76]. Due to the low distribution of irrigation facilities, water is often not available for many smallholder farms, causing frequent crop failures [41,76,77]. For instance, smallholder farms in Hararghe faced great production losses of sorghum in 2013, due to a lack of rainfall in the growing season [78]. It has been estimated that variability of rainfall may cause an average reduction in crop yields for teff, wheat, and maize of $2.4 \%, 6.2 \%$, and $10.8 \%$, respectively, by 2050 at the national level [79]. If no adaptation measures are taken, the effects of climate change and the resulting unfavorable distribution of rainfall may reduce Ethiopia's GDP by as much as $2.5 \%$ per year by 2050 and seriously affect the livelihoods of smallholder farmers [80]. 


\section{Potential Climate-Smart Agriculture Practices for Smallholder Farming Systems in Ethiopia}

In order to increase the productivity of small-scale agriculture in a sustainable way, appropriate agronomic management practices and suitable technology are needed $[8,15,30,44,54,81,82]$. This should be linked with the mitigation of climate change impacts and other relevant environmental problems (e.g., soil degradation, soil erosion, water shortages, salinization) [4,83-87]. In Ethiopia, several CSA practices are applied in smallholder farming systems (Table 1) and their current status and future potential are discussed in this section.

Table 1. Summary of potential climate-smart agriculture (CSA) practices for smallholder farming systems in Ethiopia.

\begin{tabular}{|c|c|c|}
\hline CSA Practices & Main Components & Why It Is CSA \\
\hline \multirow{4}{*}{$\begin{array}{l}\text { Conservation } \\
\text { agriculture * }\end{array}$} & Reduced tillage & Sequesters soil carbon and reduces \\
\hline & Crop residue management & greenhouse gas (GHG) emissions \\
\hline & Crop rotation/intercropping with cereals and legumes & Improves soil fertility \\
\hline & Diversifying cropping systems & Enhances resilience to dry and hot spells \\
\hline \multirow{6}{*}{$\begin{array}{l}\text { Integrated nutrient } \\
\text { management * }\end{array}$} & Compost and manure management, including green & Sequesters soil carbon \\
\hline & manuring & Increases soil resilience to drought \\
\hline & \multirow{2}{*}{$\begin{array}{c}\text { Efficient fertilizer application techniques (time, place, } \\
\text { method) }\end{array}$} & Improves soil fertility \\
\hline & & Reduces nutrient leaching \\
\hline & Combined use of inorganic fertilizers, locally available & Reduces GHG emissions \\
\hline & organic matter, and soil amendments & Increases agricultural productivity \\
\hline & Tree-based conservation agriculture & Sequesters soil and biomass carbon \\
\hline Agroforestry (AF) & Traditionally practiced AF & Supports resilience to drought \\
\hline \multirow{4}{*}{$\begin{array}{c}\text { Water harvesting and } \\
\text { irrigation }\end{array}$} & Improved types of AF & Increases agricultural productivity \\
\hline & Rainwater and runoff harvesting & Increases water availability \\
\hline & Small-scale irrigation & Enhances resilience to dry and hot spells \\
\hline & Traditional irrigation systems & Increases agricultural productivity \\
\hline
\end{tabular}

\subsection{Integrated Soil Fertility Management}

Integrated soil fertility management (ISFM), which includes and combines soil conservation practices and integrated fertilizer management, is an important measure to increase crop production and mitigate impact of climate change $[18,88]$. In recent years, special attention has been placed on ensuring that ISFM technologies are adaptable to farmers' local conditions and are also tailored to different cropping systems and socioeconomic profiles [89-91]. On-station and on-farm studies conducted in Ethiopia in different agro-ecological zones have shown that ISFM had positive effects on yields of teff, wheat, and maize [92]. A further relevant effect for Ethiopian agriculture is increased soil water retention capacity through ISFM practices [93].

\subsubsection{Conservation Agriculture Practices}

Conservation agriculture (CA) is a farming system that reduces soil degradation and prevents losses of cropland while regenerating degraded lands $[3,94,95]$. It encompasses three main principles: (I) minimizing soil disturbance through direct seeding, minimal or no-tillage, and the avoidance of excessive compaction by machinery, animals, or humans; (II) maintaining permanent soil cover through suitable crop rotations and the use of cover crops and mulch; and (III) diversifying cropping systems [9,16,68,96]. Conservation agriculture can provide various benefits to Ethiopian smallholder farming systems (Table 2). 
Table 2. Summary of major findings of conservation agriculture studies in Ethiopia.

\begin{tabular}{|c|c|c|}
\hline The Role of Conservation Agriculture & Implication for Climate-Smart Agriculture & References \\
\hline $\begin{array}{l}\text { Soil organic carbon increased by about } 0.5 \% \text { at a depth } 0-30 \mathrm{~cm} \text { by } \\
\text { minimum tillage compared to conventional tillage in Akaki district. }\end{array}$ & Carbon sequestration & {$[9,97]$} \\
\hline $\begin{array}{l}\text { Soil organic carbon increased from } 2.2 \% \text { to } 2.6 \% \text { at surface horizon } \\
\text { by conservation tillage in the Tigray region. }\end{array}$ & Carbon sequestration & [98] \\
\hline $\begin{array}{l}\text { Soil organic carbon increased by } 33 \% \text { due to conservation tillage } \\
\text { compared to conventional tillage in Amhara. }\end{array}$ & Carbon sequestration & [99] \\
\hline $\begin{array}{l}\text { Bean grain yield increased by } 32 \% \text { and soil organic matter by } 0.4 \% \\
\text { due to minimum tillage at Melkassa research center. }\end{array}$ & $\begin{array}{l}\text { Increased productivity } \\
\text { Carbon sequestration }\end{array}$ & [76] \\
\hline $\begin{array}{l}\text { Mulch increased grain yield of wheat by } 28 \% \text { in comparison to the } \\
\text { control in the Tigray region. }\end{array}$ & Increased productivity & [100] \\
\hline $\begin{array}{l}\text { Intercropped maize with crotalaria and lablab decreased emissions } \\
\text { of GHG. }\end{array}$ & Lower emissions of GHG & [101] \\
\hline $\begin{array}{l}\text { An increase of the crop diversity index by } 10 \% \text { reduced probability } \\
\text { of poverty by } 17.5 \% .\end{array}$ & $\begin{array}{l}\text { Increased productivity } \\
\text { and resilience }\end{array}$ & [102] \\
\hline $\begin{array}{l}\text { Hagarghe highlands with high diversity of cultivated crops had a } \\
\text { higher dietary diversity status }(73.9 \%) \text { than in non-diversified areas } \\
(15.2 \%) .\end{array}$ & Increased productivity and food security & [103] \\
\hline
\end{tabular}

Minimal or no tillage can enhance soil organic carbon, which is very important for soil fertility and soil structure [9,17]. In Amhara, reduced tillage increased soil organic carbon by $33 \%$ compared to conventional tillage $[76,99]$. Reduced tillage can also increase the stability of aggregates, water holding capacity, and soil moisture and, therefore, protect the soil from erosion compaction [95,98,104-107]. These effects on soil can also contribute to increasing crop yields without increasing GHG emissions [73]. Finally, conservation tillage practices can save labor and costs, which is important for resource-poor smallholder farmers and especially for female farmers $[16,96,108,109]$.

Soil cover by cover crops or mulch can help to prevent losses of soil and nutrients and has additional advantages regarding the conservation of soil moisture. For instance, covering soils by straw mulch reduced soil losses due to surface runoff by almost $100 \%$ in the highlands of Bale [87]. In northern Ethiopia, mulching with crop residues increased soil water in the root zone by more than $13 \%$ compared to a control treatment without mulch, which also affected the wheat grain yields positively [100].

The diversification of cropping systems is another approach to increase yields while reducing GHG emissions, as recently shown by Raji and Dörsch [110] for intercropped maize with crotalaria (Crotalaria juncea) and lablab (Lablab purpureus). Diversification of cropping systems also serves as a tool to improve the livelihood of the smallholder farmers $[103,111]$. In this regard, Dessie et al. [101] demonstrated that the diversification of cropping systems in northwestern parts of Ethiopia is a suitable strategy for risk reduction and to increase food security. Survey results from 15 villages in Ethiopia from 1989 to 2009 revealed that an increase of the crop diversity index by $10 \%$ reduced the probability of poverty by $17.5 \%$ [102].

Conservation agriculture has been practiced in Ethiopia for the last 20 years and its adoption level among smallholder farmers has increased [68,95]. For example, 70,000 smallholders have adopted CA in the Wolaita area to control soil erosion, improve soil fertility, and address climate variability [95]. The Agricultural Transformation Agency (ATA) of Ethiopia supported about 6000 farmers in seven Woredas (the third-level administrative divisions of Ethiopia) in 2012 and 2013 to increase conservation tillage practices, and trained hundreds of experts and development agents [23]. Apart from these promising facts, Ethiopia still has significant problems in implementing conservation farming methods in the whole country. 


\subsubsection{Integrated Nutrient Management}

Integrated nutrient management (INM) is a holistic approach and can be defined as the maintenance and regulation of soil fertility and plant nutrient supply to an optimum level in an integrated manner. It is based on the combination of organic, inorganic, and biological nutrient sources in a specific cropping system under consideration of local conditions to achieve and sustain optimum yield without harming the soil ecosystem [89,112-114]. Beside the positive effects on the soil nutrient status, INM can also enhance soil organic matter and increase the retention and storage of water $[17,115]$. Thus, it can increase the resilience of agricultural systems and contribute to increasing carbon sequestration in soils $[71,75,116]$.

Various benefits of INM have been found in Ethiopia regarding crop yields and soil organic carbon (Table 3). A meta-analysis using studies conducted in sub-Saharan Africa including Ethiopia found that mixed application of manure and inorganic fertilizer resulted in 1.1 to 4.7 times higher maize yields compared to sole application of manure or inorganic fertilizer [117]. In the Benishangul-Gumuz region, the integrated use of inorganic fertilizer and compost increased maize yield $\left(3.25 \mathrm{tha}^{-1}\right)$ and the harvest index $(1.9 \%)$ compared to sole inorganic fertilizer application [118]. In the central highlands of Ethiopia, mixed application of NP fertilizer and organic amendments increased the content of soil organic carbon by about $0.5 \%$ in comparison to sole application of NP fertilizer [116].

Table 3. Summary of major findings of integrated nutrient management (INM) studies in Ethiopia.

\begin{tabular}{|c|c|c|}
\hline Effects of Integrated Nutrient Management & Implication for Climate-Smart Agriculture & References \\
\hline $\begin{array}{l}\text { Integrated use of compost and NP }\left(55 / 10 \mathrm{~kg} \mathrm{ha}^{-1}\right) \text { resulted in higher } \\
\text { maize yield }\left(2.34 \mathrm{tha}^{-1}\right) \text { than sole application of NP } \\
\left(110 / 20 \mathrm{~kg} \mathrm{ha}^{-1}\right) .\end{array}$ & Increased productivity & [119] \\
\hline $\begin{array}{l}\text { Integrated use of NP }(30 / 10) \text { and compost produced greater maize } \\
\text { yield }\left(3.25 \mathrm{t} \mathrm{ha}^{-1}\right) \text { than sole application of NP }(60 / 20)\end{array}$ & Increased productivity & [118] \\
\hline $\begin{array}{c}\text { Mixed application organic and inorganic fertilizers increased content } \\
\text { of soil organic carbon by about } 0.5 \% \text { in comparison to sole } \\
\text { application of NP fertilizer. }\end{array}$ & Carbon sequestration & [116] \\
\hline $\begin{array}{l}\text { Mixed application of manure and inorganic fertilizer produced } 1.1 \text { to } \\
4.7 \text { times higher maize grain yields than sole application of manure } \\
\text { or inorganic fertilizer. }\end{array}$ & Increased productivity & [117] \\
\hline $\begin{array}{l}\text { Compost application increased the soil organic matter by } 3.8 \% \text { and } \\
\text { increased the availability of soil nutrients in the Amhara region. }\end{array}$ & $\begin{array}{l}\text { Carbon sequestration } \\
\text { Soil fertility }\end{array}$ & [120] \\
\hline $\begin{array}{c}\text { Straw after compost application resulted in higher yields of cereal } \\
\text { grains in the Amhara region. }\end{array}$ & Increased productivity & {$[121,122]$} \\
\hline
\end{tabular}

As an organic fertilizer, compost plays an important role because of its nutrient contents and its diverse effects on soil fertility and crop productivity. Compost application positively affects soil structure, resulting in higher resistance to erosion, improved water infiltration, and increased water holding potential, which is of great importance in Ethiopia [75]. Effects of compost application on soil chemical properties like $\mathrm{pH}$, cation exchange capacity, and electrical conductivity can result in higher bioavailability of nutrients [120]. The addition of organic matter to soil also positively affects biological soil characteristics and enhances the microbial activity of soils $[123,124]$. The low technical effort for compost production is very important for countries with a weak economy [120]. Because of these benefits, compost application has been well studied and practiced in Ethiopia. For example, compost application resulted in a better status of soil macro and micro nutrients compared to inorganic fertilizer application in Amhara region [120]. It increased maize yields in Tigray [121,125] and barley yields in Amhara [122] compared to chemical fertilizer applications. In Arsi Negelle, compost application over three years resulted in soil carbon sequestration of about $0.2 \mathrm{t} \mathrm{ha}^{-1}$ [126]. Considering the high cost for chemical fertilizer in Ethiopia, smallholder farmers are encouraged to use compost $[68,73,127]$. 
However, the availability of organic materials for soil application is a major issue. Theoretically, the annually available organic materials in Ethiopia were estimated to be $8.5 \times 10^{9} \mathrm{t}$ of poultry manure, $1.8 \times 10^{10} \mathrm{t}$ of farmyard manure, and $1.6 \times 10^{11} \mathrm{t}$ of compost [128]. This amount of organic materials could be a good basis for sustainable agricultural practices $[73,127]$, but the majority of available organic matter is used for other purposes as fuel, food for animals or construction material (see Section 2.3).

\subsection{Water Harvesting and Small-Scale Irrigation}

Water harvesting is the collecting and storing of rainwater (from rooftops and local catchments) and of seasonal floodwaters (from local streams) as well as the conservation of water through watershed management [129]. The water collection system can be categorized into I) in-situ water conservation practices, which mainly refers to the collection of water in small basins, pits, and bunds/ridges, and II) runoff-based systems, which mainly refers the collection of water from the catchment and roadside ditches [130,131].

In Ethiopia, the rainfall pattern is characterized by a large variation in spatial and temporal distributions: annual rainfall ranges between $2700 \mathrm{~mm}$ in the south-western highlands and less than $200 \mathrm{~mm}$ in some parts of the northern and south-eastern lowlands [41,132]. To compensate for the limited precipitation in certain areas, the adoption of water harvesting is very important. In addition, it is a useful mechanism to overcome the recurrent erratic rainfall and dry spell conditions, which often result in crop failures in the smallholder farming systems in Ethiopia [133]. Various benefits of water harvesting and small-scale irrigation have been found in Ethiopia (Table 4). Farmers increased their household income by $5 \%$ through using water harvesting for the production of tomatoes and onions in the Tigray region [134]. Onion cultivation with water harvesting provided higher annual income compared to rain-fed teff and wheat cultivation in the Amhara region $[130,135]$. Application of water harvesting increased the yield of teff by about $0.5 \mathrm{t} \mathrm{ha}^{-1}$, wheat by about $0.7 \mathrm{tha}^{-1}$, and barley by about $0.6 \mathrm{t} \mathrm{ha}^{-1}$ in Tigray compared to rain-fed crops [132,136]. In addition, small-scale irrigation allows the production of more crops per year on a certain area and consequently contributes to sustainable food security in Ethiopia [137]. Research findings [138,139] revealed that there is a significant welfare difference between farmers applying and farmers not applying irrigation.

Ethiopia has great potential for irrigation with 12 river basins, about 122 billion $\mathrm{m}^{3}$ annual runoff volume, and 2.6 billion $\mathrm{m}^{3}$ groundwater [130,132]. Although small-scale irrigation schemes have been promoted in sub-Saharan Africa to ensure food security, less than 5\% (640,000 ha) of the agricultural land in Ethiopia is irrigated, which includes 128,000 ha from rainwater harvesting, 383,000 ha from small-scale irrigation, and 129,000 ha from medium and large-scale irrigation $[140,141]$. Studies on irrigation schemes have shown that much of the perceived water scarcity level is rather attributed to poor water management practices, weak local institutions, unfavorable governance regimes, and financial issues than to the physical scarcity of water $[137,142,143]$ 
Table 4. Summary of major findings of water harvesting and small-scale irrigation studies in Ethiopia.

\begin{tabular}{|c|c|c|}
\hline The role of Water Harvesting and Small-Scale Irrigation & Implication for Climate-Smart Agriculture & References \\
\hline $\begin{array}{l}\text { Onion cultivation with water harvesting provided } \$ 2000 \text { higher } \\
\text { annual income compared to rain-fed teff and wheat cultivation } \\
\text { in the Amhara region. }\end{array}$ & Increased productivity & {$[130,135]$} \\
\hline $\begin{array}{c}\text { Securing adequate water availability for crops through water } \\
\text { harvesting in Tigray. }\end{array}$ & Increased resilience of cropping systems & [136] \\
\hline $\begin{array}{c}\text { In-situ rainwater harvesting provided higher maize yield }(25 \%) \\
\text { than rain-fed crops in northern Tigray. }\end{array}$ & Increased productivity & {$[135,144]$} \\
\hline $\begin{array}{l}\text { Farmers applying small-scale irrigation had a lower incidence } \\
\text { of poverty }(28 \%) \text { than the non-irrigation users }(67 \%) .\end{array}$ & Increased productivity & [137] \\
\hline $\begin{array}{l}\text { Higher yield of teff }\left(0.3-0.6 \mathrm{tha}^{-1}\right) \text {, wheat }\left(0.5-0.8 \mathrm{t} \mathrm{ha}^{-1}\right) \text {, and } \\
\text { barley }\left(0.45-0.75 \mathrm{t} \mathrm{ha}^{-1}\right) \text { obtained with small-scale irrigation } \\
\text { compared to rain-fed cropping in Tigray. }\end{array}$ & Increased productivity and resilience & [136] \\
\hline The annual income of irrigation beneficiaries in the Great Rift & & \\
\hline $\begin{array}{l}\text { Valley of Ethiopia was at about 10,200 Birr per household about } \\
\qquad 34 \% \text { higher than that of non-users. }\end{array}$ & Increased productivity and resilience & [139] \\
\hline $\begin{array}{l}\text { In Ambo district about } 60 \% \text { of farmers without irrigation } \\
\text { facilities but only about } 35 \% \text { of farmers with irrigation facilities } \\
\text { were estimated to be below the poverty line, }\end{array}$ & Decreased poverty & [138] \\
\hline
\end{tabular}

\subsection{Agroforestry}

Agroforestry is a farming practice of cultivating trees in combination with crops and/or livestock. It can provide additional food, fuel woods, and various ecosystem advantages such as increased soil fertility and carbon sequestration, as well as less soil erosion and land degradation [3,145-147]. Agroforestry allows smallholder farmers to produce various goods and services in an integrated manner to address a broader range of demands [148]. Therefore, it has been widely recognized as a good strategy to cope with food insecurity and climate change in developing countries [146,149].

In Ethiopia, various types of agroforestry have been practiced, e.g., home garden, treecrop intercropping, parkland or scattered trees in croplands, and shaded perennial-crop systems. They have contributed to enhanced food security, resilience to climate change, and carbon sequestration (Table 5). For example, agroforestry adopters received about $17 \%$ higher yields [150] and about 7\% higher incomes [31] than non-adopters in the Amhara region. As trees can obtain moisture from the underground water through their deep root systems, they can still grow in times of water shortages $[149,150]$ and produce various fruits, which are sources of supplementary food and income generation for smallholder farmers in Ethiopia [31,145]. Studies conducted in eastern Tigray [151] and the south-eastern Rift Valley escarpment [127] highlighted the increased carbon sequestration by agroforestry while protecting native trees. The increased fertility of agricultural land was the most common reason (about $40 \%$ ) for farmers to practice agroforestry [27]. 
Table 5. Summary of major findings of agroforestry studies in Ethiopia.

\begin{tabular}{|c|c|c|}
\hline The role of Agroforestry & Implication for Climate-Smart Agriculture & References \\
\hline $\begin{array}{c}\text { The land productivity of agroforestry adopters is } 16.6 \% \text { greater } \\
\text { than non-adopters in the Amhara region. }\end{array}$ & Increased productivity & [150] \\
\hline Agroforestry with white acacia (Faiderbia albida) sequestered & & \\
\hline $\begin{array}{c}\text { 9.7 } \mathrm{Mg} \mathrm{ha}^{-1} \text { of organic carbon more than rain-fed crop production } \\
\text { in the Tigray region. }\end{array}$ & Carbon sequestration & [151] \\
\hline $\begin{array}{c}\text { Soil organic carbon increased by } 52 \% \text { compared to annual } \\
\text { cereal rotation. }\end{array}$ & Carbon sequestration & [149] \\
\hline $\begin{array}{l}\text { Protection of native trees and increase of annual income by } 7 \% \\
\text { could be achieved by farmland agroforestry in the Amhara region }\end{array}$ & $\begin{array}{l}\text { Resilience to climate change } \\
\text { Improved livelihood }\end{array}$ & [31] \\
\hline $\begin{array}{c}\text { Aboveground and belowground carbon could be accumulated in } \\
\text { the south-eastern Rift Valley escarpment while protecting } \\
\text { native trees. }\end{array}$ & $\begin{array}{l}\text { Carbon sequestration } \\
\text { Resilience to climate change }\end{array}$ & [152] \\
\hline Restoration of degraded land in various regions of Ethiopia & $\begin{array}{l}\text { Resilience to climate change } \\
\text { Improved livelihood }\end{array}$ & [153-155] \\
\hline Promotion of ecosystem services in Southern Ethiopia & $\begin{array}{l}\text { Resilience to climate change } \\
\text { Improved livelihood }\end{array}$ & [156] \\
\hline
\end{tabular}

Despite these advantages, the practice of agroforestry is still limited in many parts of Ethiopia due to increases in fuelwood demand, agricultural intensification, and lack of knowledge about the conservation of trees [31,157]. Unsecured or ambiguous land tenure and shortage of labor were identified as further limiting factors $[27,158]$.

\section{Challenges for Adoption of Climate-Smart Agriculture Practices in Smallholder Farming Systems}

Despite the advantages of CSA, there are still various challenges hindering the adoption of CSA in smallholder farming systems. The most commonly identified challenges in Ethiopia are discussed below.

\subsection{Shrinking Cropland and Land Tenure Issues}

The size of the land holding is a major challenge for Ethiopian smallholder farmers in the adoption of new technology and practices [159]. Due to growing population pressure and the limited availability of unexploited land the size of cropland per capita has been decreasing (see Section 2.2). Farm size plays a critical role in the adoption of new technologies. Farmers with larger farms were found to be more likely to adopt CSA practices, since they could use one part of the farm for trying new techniques and the other part for conventional practices [160]. In contrast, farmers with small farms are hesitant to apply CSA practices, since they are afraid of the uncertainty of obtaining the claimed benefit [160]. As consequence, pressure on land has caused land degradation and reduced agricultural productivity in many parts of Ethiopia [24].

Land tenure is another issue for smallholder farmers. In Ethiopia, the current land management system allows farmers to use and manage the land, but they are often not the owners of the land [161,162]. This discourages farmers from investing [162,163] and, accordingly, there is a consensus that the more responsibility farmers have for the long-term management of their land, the more they are willing to undertake larger investments in land management [148]. This is especially important for the establishment of agroforestry systems, because of the long growing periods of trees. Another example is the long-term investment in stone terraces as important soil conservation structures against soil erosion, which is associated with secure land tenure [164].

Declining fertility of soil and unsustainable farming practices are often related to insecurity of farmers about their land tenure and suitable policies are needed to create an environment, which enables individual farmers as well as communities to invest in sustainable long-term land management [19]. 


\subsection{Lack of Adequate Knowledge and Information Transfer}

Lack of adequate knowledge and skills is a major constraint in the adoption of CSA practices in Ethiopia $[16,23,68]$. Ethiopia has five agro-ecological zones based on climatic factors such as temperature [165] and the amount and distribution of rainfall [166] for which completely different recommendations regarding suitable CSA are needed. Some CSA practices are more important in temperate and humid climates with higher yield levels, e.g., integrated nutrient management. Others, however, are more effective in arid and semi-arid conditions, where soil moisture needs to be conserved, e.g., conservation tillage $[83,167]$. Furthermore, changing rainfall pattern in combination with warming trends make agriculture more risky in Ethiopia and increase the demand for specific, locally adapted agricultural knowledge and technologies [54,167]. These also require additional resources in agricultural research and extension services in order to provide the data basis for appropriate decisions and recommendations [28,168]. However, new research and technology must not result in neglecting indigenous knowledge, which is also needed to make agriculture sustainable in Ethiopia [168].

Another constraint is the inefficient transfer of knowledge, skills, and technologies from governmental institutions and development agencies to the local farming communities $[23,68]$. Smallholder farmers are often afraid of adopting new practices before seeing clear evidence of successes and getting clear explanations regarding benefits and risks of the practices $[6,7,41]$. For instance, it is still a great challenge to adopt methods of water harvesting and small-scale irrigation technologies in Ethiopia. This is partly due to a lack of awareness among the farmers and insufficient information about advantages of small-scale irrigation, like diversification of crops grown, increased household income, employment opportunity, and participation in community decisions [129,130,132].

Additionally, exposure to new technology remains highly gendered, with most of the related initiatives targeted at men [169]. Women usually have less access to new technology, information, and training related to climate adaptation and CSA [170].

\subsection{Slow Return of Benefit and Lack of Financial Support}

One of the major challenges that hinder the adoption of CSA in Ethiopia is its slow return on investment. Many CSA practices, such as agroforestry, take time to provide tangible benefits to the farmers [4], but, due to the low status of the economy and lack of finance, most farmers need immediate benefits from a specific technology or practice $[16,68]$. As a result, the preference for the adoption of CSA is often lower than that of other agricultural practices with fast yield effects [4]. Farmers may also give up suitable technologies after a few years of using them due to a shortage of materials for construction, maintenance and operation, as shown for water harvesting technologies by [171]. Thus, incentives and support during the transition period as well as guarantees in the case of failure are necessary for the extension of CSA practices $[16,172]$.

Access to finances is a critical factor for smallholder farmers [173]. Financial support systems in Ethiopia can be separated into informal and formal institutions. Informal financial support institutions are (I) self-support groups for social development (Idhir/Meredaja Mahiber) and (II) traditional voluntary cooperatives (Iqub). Formal institutions are microfinance schemes, state-owned banks, and private commercial banks [173]. There are, however, problems concerning financial and institutional support. The informal financial institutions often lend money at high interest rates, so smallholder farmers face challenges paying back the loan on time. The formal finance providers support commercial farmers, but often ignore smallholder farmers [4].

\section{Opportunities for Enhancing Climate-Smart Agriculture Practices in Smallholder Farming Systems}

In order to successfully implement CSA practices, coordinated actions by farmers, researchers, the private sector, civil society, and policymakers are needed [11]. In the 
following, promising opportunities to extend the application of CSA practices in Ethiopia are discussed.

\subsection{Utilization of Degraded and Marginal Lands}

Instead of expanding agricultural lands at the expense of forest, the widely distributed degraded lands and marginal lands (around 26\% of the country; [174]) should be restored and utilized. To achieve this will involve two key changes: greater access to organic materials for soil management and alternative energy sources to reduce land clearing and degradation.

Access to and use of organic inputs is one of the most suitable methods to increase the fertility of degraded soils and an important CSA practice $[16,30,68,175]$ (see also Section 3.1). However, biomass is commonly used as an energy source in the rural part of Ethiopia [176,177] (see also Section 2.3). Therefore, it is important to introduce and adopt appropriate measures to increase energy efficiency and to use alternative energy sources. Various types of improved cook stoves have been developed in Ethiopia (e.g., Mirt, Mirchaye, Lakech, and Rocket stoves) and their fuel efficiency is about 30 to $40 \%$ higher than conventional cook stoves (e.g., open fire) [178-180]. This can reduce significantly the use of biomass as an energy source. Furthermore, Ethiopia has great potential to produce renewable energy from sources other than biomass [178]. Potential renewable energy sources in Ethiopia are solar energy $\left(500 \mathrm{MW} \mathrm{km}{ }^{-2}\right.$ in the lowlands and $100 \mathrm{MW} \mathrm{km}^{-2}$ in the highlands), hydropower (about $45 \mathrm{GW}$ potential), wind energy (about $10 \mathrm{GW}$ potential), and geothermal energy (about $5 \mathrm{GW}$ potential) [58]. Increasing awareness among smallholder farmers to fully exploit the locally available organic materials can also help to provide organic fertilizers to soils. For example, coffee husk is especially common in the highland area of Ethiopia. In the Shabedino district in southern Ethiopia, a small coffee-producing village dumps about $7000 \mathrm{t}$ of dry coffee husk in rivers annually [181]. This suggests a large quantitative potential of coffee wastes as organic soil amendment in regions with coffee production. The coffee husk can be used as a mulching material to prevent moisture losses and as a feedstock for producing compost, which can improve soil fertility and crop production [181,182]. Residues from khat or chat (Catha edulis) are other locally available and cheap organic sources and can be a basis for compost production. It was found that khat vermicompost had relatively high nutrients $(1.6 \% \mathrm{~N}, 0.6 \% \mathrm{P})$ [183]. Another promising opportunity of using wastes to increase the fertility of soils is to produce biochar from wastes of the meat processing industry [65]. In addition, composting organic waste such as food waste and garden waste, which is disposed of in urban Ethiopia, can also be sources of organic fertilizer for agricultural use, as long as it does not contain critical levels of harmful substances [183-185].

Salinity and waterlogging are also key issues for Ethiopia's agriculture and often reasons for land degradation [186]. Appropriate water management practices, drainage systems, and irrigation methods can mitigate these problems and increase the availability of productive agricultural land [187]. For example, in the Awash Basin, reclaimed saline fields increased sugarcane production by $50 \%$ [188]. Challenges in relation to costs and technology in the design, implementation, and operation of drainage and irrigation systems can be overcome by introducing low-cost technologies [186]. For instance, an improved water management and surface drainage method, called "broad bed and furrow", has been introduced in several parts of Ethiopia [189]. The mapping of spatial and temporal dimensions of waterlogging and salinity can help to better describe their impacts on the agricultural productivity and thus to initiate appropriate measures [186].

Degraded land which is not suitable for the pure production of crops should be converted to agroforestry, since agroforestry is one of the most promising CSA practices [190] and has a great potential to improve soil fertility $[7,19,146]$ (see also Section 3.3). In particular agroforestry systems that contain leguminous tree species are vital since they provide additional value due to biological nitrogen fixation [191]. 
On-farm trees and a return to a more diverse agricultural landscape mosaic may provide provisioning and other ecosystem services [52,153,192]. Especially in landscapes dominated by cropland, the benefit of such tree-planting is very high and linked to greater livestock numbers, improved resilience and diversification of income sources, and increased biodiversity [155]. Thus, trees can be seen as a sustainable intensification of agriculture [153]. Eucalyptus is often chosen for tree-planting, as it is a lucrative form of income [32]. However, eucalyptus trees can have a negative impact on the environment (e.g., due to their high water consumption) and more emphasis should be placed on the establishment and management of mixed-species woodlots [154,156].

Interdisciplinary landscape approaches that promote agricultural productivity as well as ecological functions should be applied in order to regenerate agricultural land, contribute to rural livelihood, and conserve biodiversity in landscapes where farmers co-exist with nature $[32,148,153,154]$. This is also addressed in the Forest Landscape Restoration (FLR) program. With 15 million ha, Ethiopia is one of the countries with the most ambitious FLR targets [52]. A main objective of this strategy is to restore degraded and marginal landscapes in order to mitigate impacts of climate change [193,194]. This program will have particular advantages for smallholder farmers as the most vulnerable to landscape degradation and the greatest beneficiaries of restoration [159].

\subsection{Providing Microfinance for the Adoption of Climate-Smart Agriculture Practices}

Access to financial support services strongly influences the decision of smallholder farmers to apply suitable CSA practices [73]. Financial support, however, also requires an increased awareness of the farmers of the financial opportunities [195], and often farmers must be trained regarding their rights of credit use and the obligation to repay in time [7]. There are various international programs that support climate funds in Ethiopia which can be useful for smallholder farmers to shift their farming system to CSA and to overcome barriers such as poor equipment and lack of inputs [14]. They include the Scaling-Up Renewable Energy Program for low-income countries (SREP) of the Climate Investment Funds (CIF), the Global Environment Facility (GEF), and the Clean Development Mechanism (CDM) $[4,196]$. They provide financial support for climate-related projects either to mitigate the impact of climate change or to increase the resilience potential of the agricultural and environmental sectors. In addition, the REDD+ program is a relevant CSA funding option administered directly through United Nations agencies and implemented by the United Nations Environment Programme (UNEP) [14,74,80]. This program makes investments in small and medium-sized enterprises dealing in clean energy solutions in rural areas, thereby increasing climate change mitigation.

Some regional organizations like banks and microfinance institutes also provide financial support for CSA investments of smallholder farmers. For example, Oromia Cooperative Bank of Ethiopia (OCBE) supports local agri-businesses related to sustainable agricultural production in smallholder farming systems [7]. The development of specialized finance schemes throughout the country and a strong framework from federal schemes to local institutions could provide even more effective support of CSA practices in smallholder farming $[4,196]$.

\subsection{Education, Empowerment, and Capacity-Building}

Training is an important capacity-building tool to disseminate CSA practices and for agricultural extension workers to pass on their knowledge to the farmers in a targeted manner $[3,96]$. Besides theoretical information, the practical aspects should also be transferred in order to increase the adoption of CSA practices. For example, practical training is often needed regarding suitable soil nutrient management, compost preparation from locally available materials, conservation agriculture, and water harvesting techniques, because these practices are very dependent on the respective local circumstances $[4,162]$. As a result of such targeted teaching, the farmers would have more experience and can easily familiarize themselves with CSA practices [96]. Most farmers prefer to see at firsthand 
the workability and applicability of new technologies and practices and to compare them with their own farming practices. Knowledge-sharing and joint educational activities allow farmers, extension workers, NGOs, and researchers to learn about success stories and the challenges associated with local CSA practices [23]. Ultimately, farmers should be empowered to develop solutions and make decisions on their own [197].

Women usually have less access to new technologies and training related to climate adaptation and CSA $[169,170]$ (see also Section 4.2). Gender mainstreaming can increase women's potential to access useful information and training on new technologies $[3,166]$. Education and training on CSA practices can also enhance opportunities and reputation of women in rural areas [23]. For example, a study indicated that women's skills have been increased through training on compost preparation from locally available materials, water harvesting systems, and small-scale irrigation schemes [28]. This training has finally increased the income of women in rural Ethiopia [198]. Empowering women means increasing their power to think and act freely, exercise choice, and to fulfil their potential as full and equal members of society [199]. However, gender empowerment cannot only be achieved through training and education. Allowing the participation of women in the process of decision-making and giving them access to inputs and resources is just as important $[28,200]$. In addition, increasing the engagement of women in political, social, and economic issues can in turn increase the adoption of CSA among smallholder farmers in Ethiopia $[28,198]$.

In addition, theoretical and practical aspects of CSA should be more incorporated in higher education curricula [201]. As education raises the awareness on both problems and solutions of land management, it also has a positive impact on investments in CSA practices [85].

\subsection{Policy Support for the Implementation of Climate-Smart Agriculture Practices}

Policy support is fundamental for the spread of CSA practices in the country. In the past decades several policies and strategies have been established for the agriculture sector to reduce poverty, especially for rural smallholder farmers in Ethiopia. These include the Agricultural-Led Industrialization (ADLI), according to which a rapid growth in agricultural production, increased income for rural households (especially for crop producers), and national food self-sufficiency can be obtained [61,202]. ADLI was later complemented by programs such as the Sustainable Development and Poverty Reduction Program (SDPRP) (2000 to 2005), a Plan for Accelerated and Sustained Development to End Poverty (PASDEP) (2005 to 2010), and the Growth and Transformation Program I (2010 to 2015) and II (2015 to 2020 [203]. The development of these programs show that compared to other sub-Saharan African countries, Ethiopia has an admirable record of supporting agriculture [25].

However, it becomes clear that the effects of climate change on agriculture can hamper the progress achieved so far and that practices more relevant for climate change adaptation and mitigation need to be promoted by means of specific policies. While Ethiopia does not have a standalone CSA strategy, significant efforts are made to develop policies and strategies relevant to climate change [3]. One important example is the Climate Resilient Green Economy (CRGE) strategy, which was established in 2011, targeting climate change adaptation and mitigation [166] with the aim of achieving a carbon-neutral middle-income status by 2025 in Ethiopia [3]. The policy incorporated CSA and sustainable land management for improving crop and livestock production, food security, integrated watershed management, and farmer income, while reducing GHG emissions (limiting emissions to $150 \mathrm{MtCO}_{2}$-e in 2030) [204,205]. It also explicitly includes the protecting and re-establishing forests [3] and it indicates that agroforestry is one of the initiatives to reduce pressure on forest resources while preventing soil erosion and land degradation [27]. Forest protection and extension is also a responsibility of the forest proclamation [206], which was approved in 2018 and regulates options for forest development, conservation, and utilization. The forest proclamation also contains tenure reform and states that communities and associa- 
tions can have forest ownership rights. This is an important factor to overcome the current impediments regarding forest landscape restoration (FLR), agroforestry, and the adoption of other CSA practices [207] (see Section 4.1).

These measures indicate that climate change and CSA have been recognized in the process of establishing policies and strategies in Ethiopia. However, considering the challenges described in Section 4, several suggestions can be made in order to enhance the implementation of CSA among smallholder farmers. First, a strong awareness among the community members of the need to improve their land use systems for sustainable livelihood and environmental protection must be achieved. In this regard, it is also necessary that communities are involved in relevant decision finding processes and that land use rights are clarified [19,207]. No policy or strategy will be especially successful without the involvement of the local community and the integration of the local farmers as a basic stakeholder [96]. For example, the CRGE was established at the national level to implement the projects. Since Ethiopia has five institutional levels (federal, regional, zonal, woreda, and kebele), the CRGE should also consider these structural administrative levels [80]. Second, agricultural development policy and strategy should carefully consider the specific issues related to small-scale farming and should place more emphasis on capacity-building, information dissemination systems, and institutional and financial support [6]. Third, formulating policies and strategies that promote the adoption of CSA should better consider the differing characteristics of climatic conditions and agro-ecology that are found across the country (e.g., different rainfall and temperature patterns) [3,167].

\section{Conclusions}

Agriculture in Ethiopia is dominated by smallholder farming systems, which together produce more than $90 \%$ of agricultural output and cultivates more than $90 \%$ of the entire cropland. In recent decades, agricultural production has made some progress; however, it needs further transformation to increase crop production in smallholder farming systems while adapting to and mitigating climate change. Various CSA practices have been adopted locally and studies have identified their various benefits, including increased drought resilience, household income, carbon sequestration, and GHG mitigation. However, the adoption of CSA is still low in smallholder farms due to a lack of land, resources, adequate knowledge, and financial and policy support. In our study, we comprehensively evaluated currently available CSA practices, which allow us to suggest opportunities and solutions for a sustainable improvement of smallholder farming systems. In this regard, we have particularly emphasized the following measures: (1) Improvement of soil quality and restoration of degraded and marginal land instead of expanding cropland through deforestation; (2) Providing training, education, and capacity-building for farmers and extension workers; and (3) Development of specific financing schemes and policies for smallholder farming systems. Although our study focuses on the situation in Ethiopia, the results may also be relevant for other countries, which aim at increasing agricultural production while mitigating the effects of climate change.

Author Contributions: Conceptualization: G.Z.; writing-original draft preparation: G.Z. and B.E.L.; editing: B.E.-L. and D.-G.K.; supervision: B.E.-L., D.F. and D.-G.K.; project administration: B.E.-L. All authors have read and agreed to the published version of the manuscript.

Funding: This research received no external funding. The APC is funded by Rostock University via the University Library.

Institutional Review Board Statement: Not applicable.

Informed Consent Statement: Not applicable.

Data Availability Statement: Not applicable. 
Acknowledgments: The authors would like to thank the program Excellence in Science and Technology (ExiST-KfW Project No. 51235) and the Ministry of Education of Ethiopia for the material support of the research of Gebeyanesh Worku Zerssa at the University of Rostock, Germany and Jimma University, Ethiopia. Dong-Gill Kim acknowledges support from IAEA CRP D15020.

Conflicts of Interest: The authors declare no conflict of interest.

\section{References}

1. Temesgen, M.; Hoogmoed, W.B.; Rockstrom, J.; Savenije, H.H.G. Conservation Tillage Implements and Systems for Smallholder Farmers in Semi-Arid Ethiopia. Soil Tillage Res. 2009, 104, 185-191. [CrossRef]

2. Stellmacher, T.; Kelboro, G. Family Farms, Agricultural Productivity, and the Terrain of Food (In)Security in Ethiopia. Sustainability 2019, 11, 4981. [CrossRef]

3. Njeru, E.; Grey, S.; Kilawe, E. Eastern Africa Climate-Smart Agriculture Scoping Study: Ethiopia, Kenya and Uganda; FAO: Addis Ababa, Ethiopia, 2016.

4. Aweke, M. Gelaw Climate-Smart Agriculture in Ethiopia: CSA Country Profiles for Africa Series; International Center for Tropical Agriculture: Washington, DC, USA, 2017.

5. Rapsomanikis, G. The Economic Lives of Smallholder Farmers; An Analysis Based on Household Surveys; Food and Agriculture Organization: Rome, Italy, 2015.

6. Ogato, G.S. Biophysical, Socio-Economic, and Institutional Constraints for Production and Flow of Cereals in Ethiopia. AJHE 2014, 3, 51-71. [CrossRef]

7. Gezie, M.; Tejada Moral, M. Farmer's Response to Climate Change and Variability in Ethiopia: A Review. Cogent Food Agric. 2019, 5, 1613770. [CrossRef]

8. Tessema, I.; Simane, B. Vulnerability Analysis of Smallholder Farmers to Climate Variability and Change: An Agro-Ecological System-Based Approach in the Fincha'a Sub-Basin of the Upper Blue Nile Basin of Ethiopia. Ecol. Process. 2019, 8, 5. [CrossRef]

9. Nagothu, U.S. Climate Change and Agricultural Development: Improving Resilience through Climate Smart Agriculture; Agro Ecology and Conservation; Routledge (Taylor \& Francis Group): London, UK, 2016; ISBN 9781138364080.

10. McCarthy, N.; Lipper, L.; Branca, G. Climate Smart Agriculture: Smallholder Adoption and Implications for Climate Change Adaptation and Mitigation; Food and Agriculture Organization of the United Nations (FAO): Roma, Italy, 2011; p. 37.

11. Lipper, L.; Thornton, P.; Campbell, B.M.; Baedeker, T.; Braimoh, A.; Bwalya, M.; Caron, P.; Cattaneo, A.; Garrity, D.; Henry, K.; et al. Climate-Smart Agriculture for Food Security. Nat. Clim Chang. 2014, 4, 1068-1072. [CrossRef]

12. Steenwerth, K.L.; Hodson, A.K.; Bloom, A.J.; Carter, M.R.; Cattaneo, A.; Chartres, C.J.; Hatfield, J.L.; Henry, K.; Hopmans, J.W.; Horwath, W.R.; et al. Climate-Smart Agriculture Global Research Agenda: Scientific Basis for Action. Agric. Food Secur. 2014, 3 , 11. [CrossRef]

13. Nciizah, A.D.; Wakindiki, I.I. Climate Smart Agriculture: Achievements and Prospects in Africa. J. Geosci. Environ. Prot. 2015, 3 , 99-105. [CrossRef]

14. Zougmoré, R.; Partey, S.; Ouédraogo, M.; Omitoyin, B.; Thomas, T.; Ayantunde, A.; Ericksen, P.; Said, M.; Jalloh, A. Toward Climate-Smart Agriculture in West Africa: A Review of Climate Change Impacts, Adaptation Strategies and Policy Developments for the Livestock, Fishery and Crop Production Sectors. Agric. Food Secur. 2016, 5, 26. [CrossRef]

15. Campbell, B.M.; Thornton, P.; Zougmoré, R.; van Asten, P.; Lipper, L. Sustainable Intensification: What Is Its Role in Climate Smart Agriculture? Curr. Opin. Environ. Sustain. 2014, 8, 39-43. [CrossRef]

16. Gjengedal, M. Conservation Agriculture; Food and Agriculture Organization of the United Nations (FAO): Ginbi, Ethiopia, 2016; p. 119.

17. Bai, X.; Huang, Y.; Ren, W.; Coyne, M.; Jacinthe, P.; Tao, B.; Hui, D.; Yang, J.; Matocha, C. Responses of Soil Carbon Sequestration to Climate-smart Agriculture Practices: A Meta-analysis. Glob. Chang. Biol 2019, 25, 2591-2606. [CrossRef]

18. Agegnehu, G.; Tilahun Amede, T. Integrated Soil Fertility and Plant Nutrient Management in Tropical Agro-Ecosystems: A Review. Pedosphere 2017, 27, 662-680. [CrossRef]

19. Chiemela, S.N.; Noulekoun, F.; Zenebe, A.; Abadi, N.; Birhane, E. Transformation of Degraded Farmlands to Agroforestry in Zongi Village, Ethiopia. Agroforest Syst. 2018, 92, 1317-1328. [CrossRef]

20. Headey, D.; Dereje, M.; Taffesse, A.S. Land Constraints and Agricultural Intensification in Ethiopia: A Village-Level Analysis of High-Potential Areas. Food Policy 2014, 48, 129-141. [CrossRef]

21. Mutyasira, V.; Hoag, D.; Pendell, D.; Yildiz, F. The Adoption of Sustainable Agricultural Practices by Smallholder Farmers in Ethiopian Highlands: An Integrative Approach. Cogent Food Agric. 2018, 4, 1552439. [CrossRef]

22. Wassie, A.; Pauline, N. Evaluating Smallholder Farmers' Preferences for Climate Smart Agricultural Practices in Tehuledere District, Northeastern Ethiopia: Evaluating Smallholder Farmers' Preferences. Singap. J. Trop. Geogr. 2018, 39, 300-316. [CrossRef]

23. Jirata, M.; Grey, S.; Kilawe, E. Ethiopia Climate-Smart Agriculture Scoping Study; FAO: Addis Ababa, Ethiopia, 2016.

24. Abera, W.; Assen, M.; Budds, J. Determinants of Agricultural Land Management Practices among Smallholder Farmers in the Wanka Watershed, Northwestern Highlands of EthiopiaI. Land Use Policy 2020, 99, 104841. [CrossRef]

25. Welteji, D. A Critical Review of Rural Development Policy of Ethiopia: Access, Utilization and Coverage. Agric. Food Secur. 2018, 7, 55. [CrossRef] 
26. Shikur, Z.H. Agricultural Policies, Agricultural Production and Rural Households' Welfare in Ethiopia. Econ. Struct. 2020, 9, 50. [CrossRef]

27. Beyene, A.D.; Mekonnen, A.; Randall, B.; Deribe, R. Household Level Determinants of Agroforestry Practices Adoption in Rural Ethiopia. For. Trees Livelihoods 2019, 28, 194-213. [CrossRef]

28. Tsige, M.; Synnevåg, G.; Aune, J.B. Gendered Constraints for Adopting Climate-Smart Agriculture amongst Smallholder Ethiopian Women Farmers. Sci. Afr. 2020, 7, e00250. [CrossRef]

29. Sain, G.; Loboguerrero, A.M.; Corner-Dolloff, C.; Lizarazo, M.; Nowak, A.; Martínez-Barón, D.; Andrieu, N. Costs and Benefits of Climate-Smart Agriculture: The Case of the Dry Corridor in Guatemala. Agric. Syst. 2017, 151, 163-173. [CrossRef]

30. Stewart, Z.P.; Pierzynski, G.M.; Middendorf, B.J.; Prasad, P.V.V. Approaches to Improve Soil Fertility in Sub-Saharan Africa. J. Exp. Bot. 2020, 71, 632-641. [CrossRef]

31. Amare, D.; Wondie, M.; Mekuria, W.; Darr, D. Agroforestry of Smallholder Farmers in Ethiopia: Practices and Benefits. Small Scale For. 2019, 18, 39-56. [CrossRef]

32. Hadgu, K.M.; Bishaw, B.; Iiyama, M.; Birhane, E.; Negussie, A.; Davis, C.M.; Bernart, B. Climate-Smart Agriculture; FAO: Roma, Italy, 2019.

33. Gebre-Selassie, A.; Bekele, T. A Review of Ethiopian Agriculture: Roles, Policy and Small-Scale Farming Systems. In Global Growing Casebook: Insights into African Agriculture; Global Growing Campaign, European Union: Brussels, Belgium, 2012; pp. 36-65.

34. Chipeta, M.; Emana, B.; Chanyalew, D. Ethiopia's Agriculture Sector Policy and Investment Framework (2010-2020) External Mid-Term Review; Governement of Ethiopia: Addis Ababa, Ethiopia, 2015; p. 84.

35. Paul, M.; Wa Gĩthĩnji, M. Small Farms, Smaller Plots: Land Size, Fragmentation, and Productivity in Ethiopia. J. Peasant Stud. 2017. [CrossRef]

36. Taffesse, A.S.; Dorosh, P.; Gemessa, S.A. Crop Production in Ethiopia: Regional Patterns and Trends. Food Agric. Ethiop. Prog. Policy Chall. 2013, 97, 53-83.

37. Central Statistical Agency (CSA). Report on Area and Production of Major Crops. Agricultural Sample Survey 2017/18 (2010 E.C); Central Statistical Agency: Addis Ababa, Ethiopia, 2018; Volume 1.

38. Van Loon, M.P.; Nanyan Grassini, P.; Rattalino Edreira, J.I.; Wolde-Meskel, E.; Baijukya, F.; Marrou, H.; van Ittersum, M.K. Prospect for Increasing Grain Legume Crop Production in East Africa. Eur. J. Agron. 2018, 101, 140-148. [CrossRef]

39. Central Statistical Agency (CSA). Report on Area and Production of Major Crops. Agricultural Sample Survey 2015/16 (2008 E.C); Central Statistical Agency: Addis Ababa, Ethiopia, 2016.

40. Desalegn, T.; Alemu, G.; Adella, A.; Debele, T. Effect of Lime and Phosphorus Fertilizer on Acid Soils and Barley (Hordeum Vulgare L.) Performance in the Central Highlands of Ethiopia. Exp. Agric. 2017, 53, 432-444. [CrossRef]

41. Berhane, A. Climate Change and Variability Impacts on Agricultural Productivity and Food Security. J. Climatol. Weather Forecast. 2018, 6, 1-6. [CrossRef]

42. Berhanu, Y.; Olav, L.; Nurfeta, A.; Angassa, A.; Aune, J.B. Methane Emissions from Ruminant Livestock in Ethiopia: Promising Forage Species to Reduce CH4 Emissions. Agriculture 2019, 9, 130. [CrossRef]

43. Berhanu, Y.; Angassa, A.; Aune, J.B. A System Analysis to Assess the Effect of Low-Cost Agricultural Technologies on Productivity, Income and GHG Emissions in Mixed Farming Systems in Southern Ethiopia. Agric. Syst. 2021, 187. [CrossRef]

44. Tesfa, A.; Mekuriaw, S. The Effect of Land Degradation on Farm Size Dynamics and Crop-Livestock Farming System in Ethiopia: A Review. OJSS 2014, 4, 1-5. [CrossRef]

45. Mekuria, W.; Mekonnen, K. Determinants of Crop-Livestock Diversification in the Mixed Farming Systems: Evidence from Central Highlands of Ethiopia. Agric. Food Secur. 2018, 7, 60. [CrossRef]

46. Duncan, A.J.; Bachewe, F.; Mekonnen, K.; Valbuena, D.; Rachier, G.; Lule, D.; Bahta, M.; Erenstein, O. Crop Residue Allocation to Livestock Feed, Soil Improvement and Other Uses along a Productivity Gradient in Eastern Africa. Agric. Ecosyst. Environ. 2016, 228, 101-110. [CrossRef]

47. Mengistu, H. Competitive Uses of Crop Residues Are Challenging Soil Fertility Management in Ethiopia. Int. J. Curr. Res. 2018, 10, 65139-65144.

48. Assaminew, S.; Ashenafi, M. Assessment of Feed Formulation and Feeding Level of Urban and Periurban Dairy Cows Nexus with Economic Viability in Central Highland of Ethiopia. Available online: https://www.lrrd.cipav.org.co/lrrd27/7/assa27125.htm (accessed on 8 February 2021).

49. Mekuria, W.; Aynekulu, E. Exclosure land management for restoration of the soils in degraded communal grazing lands in northern ethiopia: Exclosures restore degraded soil. Land Degrad. Dev. 2013, 24, 528-538. [CrossRef]

50. Giday, K.; Humnessa, B.; Muys, B.; Taheri, F.; Azadi, H. Effects of Livestock Grazing on Key Vegetation Attributes of a Remnant Forest Reserve: The Case of Desa'a Forest in Northern Ethiopia. Glob. Ecol. Conserv. 2018, 14, e00395. [CrossRef]

51. Kikoti, I.A.; Mligo, C. Impacts of Livestock Grazing on Plant Species Composition in Montane Forests on the Northern Slope of Mount Kilimanjaro, Tanzania. Int. J. Biodivers. Sci. Ecosyst. Serv. Manag. 2015, 11, 114-127. [CrossRef]

52. Pistorius, T.; Carodenuto, S.; Wathum, G. Implementing Forest Landscape Restoration in Ethiopia. Forests 2017, 8, 61. [CrossRef]

53. Bekele, A.E.; Drabik, D.; Dries, L.; Heijman, W. Large-Scale Land Investments, Household Displacement, and the Effect on Land Degradation in Semiarid Agro-Pastoral Areas of Ethiopia. Land Degrad. Dev. 2021, 32, 777-791. [CrossRef] 
54. Tesfaye, K.; Seid, J.; Getnet, M.; Mamo, G. Agriculture under a Changing Climate in Ethiopia: Challenges and Opportunities for Research. Ethiop. J. Agric. Sci. 2016, 6, 67-86.

55. Kidane, M. The Impact of Land Use and Land Cover (LULC) Dynamics on Soil Erosion and Sediment Yield in Ethiopia. Heliyon 2019, 5, e02981. [CrossRef] [PubMed]

56. Schmidt, E.; Thomas, T.S. Cropland Expansion in Ethiopia: Economic and Climatic Considerations for Highland Agriculture; International Food Policy Research Institute (IFPRI): Washington, DC, USA, 2018; Volume 127.

57. Ethiopian Development Research Institute (EDRI). Preliminary Assessment by the EDRI of Impacts, Cost and Feasibility of Strategy Options-Climate Resilient Green Growth Initiative; Ethiopian Development Research Institute: Addis Ababa, Ethiopia, 2010.

58. Mondal, M.A.H.; Bryan, E.; Ringler, C.; Mekonnen, D.; Rosegrant, M. Ethiopian Energy Status and Demand Scenarios: Prospects to Improve Energy Efficiency and Mitigate GHG Emissions. Energy 2018, 149, 161-172. [CrossRef]

59. MoARD. Ethiopia Agricultural Sector Policy and Investment Framework 2010-2020; Ministry of Agriculture and Rural Development: Addis Ababa, Ethiopia, 2010.

60. Tessema, Y.A.; Aweke, C.S.; Endris, G.S. Understanding the Process of Adaptation to Climate Change by Small-Holder Farmers: The Case of East Hararghe Zone, Ethiopia. Agric. Econ. 2013, 1, 13. [CrossRef]

61. Dutch Ministry of Foreign Affairs (DMoFA). The Future of Work for Smallholder Farmers in Ethiopia. In Policy Paper by The West Wing Think Tank for the Dutch Ministry of Foreign Affairs.; 2019; p. 1. Available online: https:// www.Government.Nl/Documents / Reports/2019/07/08/West-Wing (accessed on 13 June 2020).

62. International Fertilizer Development Center (IFDC); Food and Agriculture Organization of the United Nations (FAO). Assessment of Fertilizer Consumption and Use by Crop in Ethiopia; International Fertilizer Development Center (IFDC): Muscle Shoals, AL, USA, 2016.

63. Agricultural Transformation Agency (ATA). Ethiopian Agriculture and Strategies for Growth; Agricultural Transformation Agency (ATA): Addis Ababa, Ethiopia, 2017.

64. Lassaletta, L.; Billen, G.; Grizzetti, B.; Anglade, J.; Garnier, J. 50 Year Trends in Nitrogen Use Efficiency of World Cropping Systems: The Relationship between Yield and Nitrogen Input to Cropland. Environ. Res. Lett. 2014, 9, 105011. [CrossRef]

65. Nigussie, A.; Kuyper, T.W.; de Neergaard, A. Earthworms Change the Quantity and Composition of Dissolved Organic Carbon and Reduce Greenhouse Gas Emissions during Composting. Waste Manag. 2017, 62, 43-51. [CrossRef]

66. Haileslassie, A.; Priess, J.A.; Veldkamp, E.; Lesschen, J.P. Smallholders' Soil Fertility Management in the Central Highlands of Ethiopia: Implications for Nutrient Stocks, Balances and Sustainability of Agroecosystems. Nutr. Cycl. Agroecosyst. 2006, 75, 135-146. [CrossRef]

67. Assefa, K. Biogas Residues as Source of Sulfur to Pak Choi Brassica Rapa Var. Chinensis (L.). J. Soil Sci. Environ. Manag. 2013, 4, 163-168. [CrossRef]

68. Mohammed, E. Opportunities and Challenges for Adopting Conservation Agriculture at Smallholder Farmer's Level: The Case of Emba Alage, Tigray, Northern Ethiopia; Addis Ababa University: Addis Ababa, Ethiopia, 2016.

69. Gebrekidan, T.; Guo, Y.; Bi, S.; Wang, J.; Zhang, C.; Wang, J.; Lyu, K. Effect of Index-Based Livestock Insurance on Herd Offtake: Evidence from the Borena Zone of Southern Ethiopia. Clim. Risk Manag. 2019, 23, 67-77. [CrossRef]

70. Komarek, A.M.; Thurlow, J.; Koo, J.; De Pinto, A. Economywide Effects of Climate-smart Agriculture in Ethiopia. Agric. Econ. 2019, 50, 765-778. [CrossRef]

71. Abraha, R.; Alem H, H. Extensive Utilization of Inorganic Fertilizers in Ethiopian Agriculture and Its Possible Consequences on Soil Quality. World J. Agric. Sci. 2017, 13, 155-171.

72. Teshome, A.; de Graaff, J.; Ritsema, C.; Kassie, M. Farmers' Perceptions about the Influence of Land Quality, Land Fragmentation and Tenure Systems on Sustainable Land Management in the North Western Ethiopian Highlands: Sustainable land management in the north western ethiopian highlands. Land Degrad. Dev. 2016, 27, 884-898. [CrossRef]

73. Abebe, G.; Debebe, S. Factors Affecting Use of Organic Fertilizer among Smallholder Farmers in Sekela District of Amhara Region, Northwestern Ethiopia. Cogent Food Agric. 2019, 5, 1-11. [CrossRef]

74. Palombi, L.; Sessa, R. Climate-Smart Agriculture: Sourcebook. Climate-Smart Agriculture; Sourcebook; FAO: Roma, Italy, 2013.

75. Smith, J.H.; Nayak, D.; Albanito, F.; Balana, B.; Black, H.; Boke, S.; Phimister, E. Treatment of Organic Resources before Soil Incorporation in Semi-Arid Regions Improves Resilience to El Nino, and Increases Crop Production and Economic Returns. Environ. Res. Lett. 2019, 14, 085004. [CrossRef]

76. Liben, F.M.; Tadesse, B.; Tola, Y.T.; Wortmann, C.S.; Kim, H.K.; Mupangwa, W. Conservation Agriculture Effects on Crop Productivity and Soil Properties in Ethiopia. Agron. J. 2018, 110, 758-767. [CrossRef]

77. Binyam, A.Y.; Desale, K.A. Rainwater Harvesting: An Option for Dry Land Agriculture in Arid and Semi-Arid Ethiopia. Int. J. Water Resour. Environ. Eng. 2015, 7, 17-28. [CrossRef]

78. Shumetie, A.; Alemayehu, Y.M. Effect of Climate Variability on Crop Income and Indigenous Adaptation Strategies of Households Int. J. Clim. Chang. Strateg. Manag. 2018, 10, 580-595. [CrossRef]

79. Kelbore, Z.G. An Analysis of the Impact of Climate Change on Crop Yields and Yield Variability. Appl. Econ. 2012, 38, 835-844.

80. Paul, C.J.; Weinthal, E. The Development of Ethiopia's Climate Resilient Green Economy 2011-2014: Implications for Rural Adaptation. Clim. Dev. 2019, 11, 193-202. [CrossRef]

81. Assefa, T.B.; Jordan, C.; Pytrik, R.; João, V.S.; Martin, K. Unravelling the Variability and Causes of Smallholder Maize Yield Gaps in Ethiopia. Food Secur. 2019, 12, 83-103. [CrossRef] 
82. Yang, K.F.; Gergel, S.E.; Baudron, F. Forest Restoration Scenarios Produce Synergies for Agricultural Production in Southern Ethiopia. Agric. Ecosyst. Environ. 2020, 295, 106888. [CrossRef]

83. Kassie, M.; Zikhali, P.; Pender, J.; Köhlin, G. Sustainable Agricultural Practices and Agricultural Productivity in Ethiopia: Does Agroecology Matter? Discussions Paper; Environment for the Development Initiative: Washington, DC, USA, 2009 ; pp. 9-12.

84. Sime, G.; Aune, J.B. Sustainability of Improved Crop Varieties and Agricultural Practices: A Case Study in the Central Rift Valley of Ethiopia. Agriculture 2018, 8, 177. [CrossRef]

85. Adimassu, Z.; Langan, S.; Johnston, R. Understanding Determinants of Farmers' Investments in Sustainable Land Management Practices in Ethiopia: Review and Synthesis. Env. Dev. Sustain. 2016, 18, 1005-1023. [CrossRef]

86. Annys, S.; Van Passel, S.; Dessein, J.; Ghebreyohannes, T.; Adgo, E.; Nyssen, J. Small-Scale Irrigation Expansion along the Dam-Regulated Tekeze River in Northern Ethiopia. Int. J. Water Resour. Dev. 2020, 1-22. [CrossRef]

87. Birru, O.; Quraishi, S.; Bedadi, B. Effects of Straw Mulch and Farmyard Manure on Runoff, Erosion, in-Situ Water Conservation, and Yield and Yield Components of Wheat at the Highlands of Bale, South Eastern Ethiopia. Afr. J. Agric. Res. 2012, 7, 5879-5886.

88. Vanlauwe, B.; Bationo, A.; Giller, K.E.; Merckx, R.; Mokwunye, U.; Ohiokpehai, O.; Sanginga, N. Integrated Soil Fertility Management. Operational Definition and Consequences for Implementation and Dissemination. Outlook Agric. 2010, 39, 17-24. [CrossRef]

89. Yebo, B. Integrated Soil Fertility Management for Better Crop Production in Ethiopia. Int. J. Soil Sci. 2014, 10, 1-16. [CrossRef]

90. Vanlauwe, B.; Bationo, A.; Giller, K.E.; Merckx, R.; Mokwunye, U.; Ohiokpehai, O.; Sanginga, N. Integrated Soil Fertility Management in Sub-Saharan Africa: Unravelling Local Adaptation. Soil 2015, 1, 491-508. [CrossRef]

91. Mugwe, J.; Ngetich, F.; Otieno, E.O. Integrated Soil Fertility Management in Sub-Saharan Africa: Evolving Paradigms Toward Integration. Zero Hunger. Encyclopedia of the UN Sustainable Development Goals; Springer: Cham, Germany, 2019. [CrossRef]

92. Hörner, D.; Wollni, M. The Effects of Integrated Soil Fertility Management on Household Welfare in Ethiopia; University of Göttingen: Göttingen, Germany, 2020; p. 38.

93. Habte Werede, M.; Smith, J.U.; Boke Ambaye, S.; Tejada Moral, M. Integrated Soil Fertility Management for Sustainable Teff (Eragrostistef) Production in Halaba, Southern Ethiopia. Cogent Food Agric. 2018, 4, 1519008. [CrossRef]

94. Giller, K.E.; Witter, E.; Corbeels, M.; Tittonell, P. Conservation Agriculture and Smallholder Farming in Africa: The Heretics' View. Field Crop. Res. 2009, 114, 23-34. [CrossRef]

95. Ram, B.S.; Andy, S.; Nyambilila, A.A.; Lars, O.E.; Bishal, K.S.; Rattan, L. Climate Impacts on Agricultural and Natural Resource Sustainability in Africa; Springer Nature Switzerland: Cham, Switzerland, 2020.

96. Tsegaye, W.; LaRovere, R.; Mwabu, G.; Kassie, G.T. Adoption and Farm-Level Impact of Conservation Agriculture in Central Ethiopia. Environ. Dev. Sustain. 2017, 19, 2517-2533. [CrossRef]

97. Wakayo, A.; Urgessa, T. Potential of Small Holder Farmers Agricultural Practices in Enhancing Soil Organic Carbon Stock and Other Selected Soil Physico Properties at Akaki District, Ethiopia. Agric. For. Fish. 2020, 8, 112. [CrossRef]

98. Oicha, T.; Cornelis, W.M.; Verplancke, H.; Nyssen, J.; Govaerts, B.; Behailu, M.; Deckers, J. Soil Tillage Research Short-Term Effects of Conservation Agriculture on Vertisols under Tef (Eragrostistef (Zucc.) Trotter) in the Northern Ethiopian Highlands. Soil Tillage Res. 2010, 106, 294-302. [CrossRef]

99. Getnet, K.; Mekuria, W.; Langan, S.; Rivington, M.; Novo, P.; Black, H. Ecosystem-Based Interventions and Farm Household Welfare in Degraded Areas: Comparative Evidence from Ethiopia. Agric. Syst. 2017, 154, 53-62. [CrossRef]

100. Araya, A.; Stroosnijder, L. Effects of Tied Ridges and Mulch on Barley (Hordeum Vulgare) Rainwater Use Efficiency and Production in Northern Ethiopia. Agric. Water Manag. 2010, 97, 841-847. [CrossRef]

101. Dessie, A.B.; Abate, T.M.; Mekie, T.M.; Liyew, Y.M. Crop Diversification Analysis on Red Pepper Dominated Smallholder Farming System: Evidence from Northwest Ethiopia. Ecol. Process. 2019, 8, 50. [CrossRef]

102. Michler, J.D.; Josephson, A. To Specialize or Diversify: Agricultural Diversity and Poverty Dynamics in Ethiopia. World Dev. 2017, 89, 214-226. [CrossRef]

103. Goshu, D.; Kassa, B.; Ketema, M. Does crop diversification enhance household food security? evidence from rural ethiopia. Adv. Agric. 2012, 2, 13.

104. Milder, J.C.; Scherr, S.J. Performance and Potential of Conservation Agriculture for Climate Change Adaptation and Mitigation in Sub-Saharan Africa. Eco-Agriculture Discussion Paper 6. 2011. Available online: https://www.researchgate.net/publication/26 8524125 (accessed on 12 January 2019).

105. Araya, T.; Cornelis, W.M.; Nyssen, J.; Govaerts, B.; Getnet, F.; Bauer, H.; Deckers, J. Medium-Term Effects of Conservation Agriculture Based Cropping Systems for Sustainable Soil and Water Management and Crop Productivity in the Ethiopian Highlands. Field Crop. Res. 2012, 132, 53-62. [CrossRef]

106. Gadermaier, F.; Berner, A.; Fließbach, A.; Friedel, J.K.; Mäder, P. Impact of Reduced Tillage on Soil Organic Carbon and Nutrient Budgets under Organic Farming. Renew. Agric. Food Syst. 2012, 27, 68-80. [CrossRef]

107. De Araújo, A.S.F.; Leite, L.F.C.; Miranda, A.R.L.; Nunes, L.A.P.L.; de Sousa, R.S.; de Araújo, F.F.; de Melo, W.J. Different Soil Tillage Systems Influence Accumulation of Soil Organic Matter in Organic Agriculture. Afr. J. Agric. Res. 2016, 11, 5109-5115.

108. Mesfin, T.; Moeller, C.; Rodriguez, D.; Temesgen, M. Conservation Agriculture in Dryland Agro-Ecosystems of Ethiopia. In Proceedings of the 5th World Congress on Conservation Agriculture and Farming Systems Design, Brisbane, Australia, 26-29 September 2011. 
109. Gonzalez-Sanchez, E.J.; Veroz-Gonzalez, O.; Conway, G.; Moreno-Garcia, M.; Kassam, A.; Mkomwa, S.; Carbonell-Bojollo, R. Meta-Analysis on Carbon Sequestration through Conservation Agriculture in Africa. Soil Tillage Res. 2019, 190, 22-30. [CrossRef]

110. Raji, S.G.; Dörsch, P. Effect of Legume Intercropping on $\mathrm{N}_{2} \mathrm{O}$ Emissions and $\mathrm{CH}_{4}$ Uptake during Maize Production in the Great Rift Valley, Ethiopia. Biogeosciences 2020, 17, 345-359. [CrossRef]

111. Teklewold, H.; Kassie, M.; Shiferaw, B.; Köhlin, G. Cropping System Diversification, Conservation Tillage and Modern Seed Adoption in Ethiopia: Impacts on Household Income, Agrochemical Use and Demand for Labor. Ecol. Econ. 2013, 93, 85-93. [CrossRef]

112. Lamessa, K. Integrated Nutrient Management for Food Security and Environmental Quality. Food Sci. Qual. Manag. 2016, 56, 2224-6088

113. Yigermal, H.; Kelemu, N.; Fenta, A. Effects of Integrated Nutrient Application on Phenological, Vegetative Growth and YieldRelated Parameters of Maize in Ethiopia: A Review. Cogent Food Agric. 2019, 5, 1567998. [CrossRef]

114. Eichler-Loebermann, B.; Schiemenz, K.; Makadi, M.; Vágó, I.; Koeppen, D. Nutrient Cycling by Using Residues of Bio-Energy Production-Effects of Biomass Ashes on Plant and Soil Parameters. Cereal Res. Commun. 2008, 36, 1259-1262.

115. Kim, D.G.; Thomas, A.D.; Pelster, D.; Rosenstock, T.S.; Sanz-Cobena, A. Greenhouse Gas Emissions from Natural Ecosystems and Agricultural Lands in Sub-Saharan Africa: Synthesis of Available Data and Suggestions for Further Research. Biogeosciences 2016, 13, 4789-4809. [CrossRef]

116. Agegnehu, G.; vanbeek, C.; Bird, M.I. Influence of Integrated Soil Fertility Management in Wheat and Tef Productivity and Soil Chemical Properties in the Highland Tropical Environment. J. Soil Sci. Plant. Nutr. 2014, 14, 532-545. [CrossRef]

117. Sileshi, G.W.; Jama, B.; Vanlauwe, B.; Negassa, W.; Harawa, R.; Kiwia, A.; Kimani, D. Nutrient Use Efficiency and Crop Yield Response to the Combined Application of Cattle Manure and Inorganic Fertilizer in Sub-Saharan Africa. Nutr. Cycl. Agroecosyst. 2019, 113, 181-199. [CrossRef]

118. Biramo, G. The Role of Integrated Nutrient Management System for Improving Crop Yield and Enhancing Soil Fertility under Small Holder Farmers in Sub-Saharan Africa: A Review Article. Mod. Concepts Dev. Agron. 2018, 2, 1-9. [CrossRef]

119. Negassa, W.; Getaneh, F.; Deressa, A.; Dinsa, B. Integrated Use of Organic and Inorganic Fertilizers for Maize Production; Tropentag: Witzenhausen, Germany, 2007.

120. Adugna, G. A Review on Impact of Compost on Soil Properties, Water Use and Crop Productivity. Acad. Res. J. Agric. Sci. Res. 2016, 4, 93-104. [CrossRef]

121. Edwards, S.; Arefayne, A. The Impact of Compost Use on Crop. Yields in Tigray, Ethiopia. International Conference on Organic Agriculture and Food Security; FAO: Rome, Italy, 2007. Available online: http:/ /www.fao.org/3/a-ai434e.pdf (accessed on 20 June 2020).

122. Agegnehu, G.; Tsigie, A.; Tesfaye, A. Evaluation of Crop Residue Retention, Compost and Inorganic Fertilizer Application on Barley Productivity and Soil Chemical Properties in the Central Ethiopian Highlands. Ethiop. J. Agric. Sci. 2012, 22, 45-61.

123. Krey, T.; Vassilev, N.; Baum, C.; Eichler-Löbermann, B. Effects of Long-Term Phosphorus Application and Plant Growth Promoting Rhizobacteria on Maize Phosphorus Nutrition under Field Conditions. Eur. J. Soil Biol. 2013, 55, 124-130. [CrossRef]

124. Requejo, M.I.; Eichler-Löbermann, B. Organic and Inorganic Phosphorus Forms in Soil as Affected by Long-Term Application of Organic Amendments. Nutr. Cycl. Agroecosyst. 2014, 100, 245-255. [CrossRef]

125. Kassie, M.; Zikhali, P.; Manjur, K.; Edwards, S. Adoption of Organic Farming Technologies: Evidence from Semi-Arid Regions of Ethiopia. J. Agric. Econ. 2008, 33, 189-198.

126. Haile, W. Review of Soil Fertility Interventions in Ethiopia. Ph.D. Thesis, Soil Science College of Agriculture, Hawassa University, Awassa, Ethiopia, 2017. [CrossRef]

127. Asfaw, S.; Shiferaw, B.; Simtowe, F.; Lipper, L. Impact of Modern Agricultural Technologies on Smallholder Welfare: Evidence from Tanzania and Ethiopia. Food Policy 2012, 37, 283-295. [CrossRef]

128. Devi, R.; Kumar, A.; Deboch, B. Organic Farming and Sustainable Development in Ethiopia. Sci. Res. Essays 2007, 2, $199-203$.

129. Alem, G. Rainwater Harvesting in Ethiopia: An Overview. In Integrated Development for Water Supply and Sanitation: Proceedings of the 25th WEDC Conference, Addis Ababa, Ethiopia, 30 August-2 September 1999; Water, Engineering and Development Centre (WEDC): Loughborough, UK, 2000; pp. 387-390.

130. Mengistie, D.; Kidane, D. Assessment of the Impact of Small-Scale Irrigation on Household Livelihood Improvement at Gubalafto District, North Wollo, Ethiopia. Agriculture 2016, 6, 27. [CrossRef]

131. Awulachew, S.B.; Ayana, M. Performance of irrigation: An assessment at different scales in ethiopia. Exp. Agric. 2011, 47, 57-69. [CrossRef]

132. Tesfay, G.; Mitiku, H.; Girmay, G.; Araya, A.; Daniel, T.; Wubetu, B.; Dereje, A. On-Farm. Water Harvesting for Rainfed Agriculture Development and Food Security in Tigray, Northern Ethiopia; Drylands Coordination Group Report, 61; FAO: Oslo, Norway, 2011.

133. Dile, Y.T.; Karlberg, L.; Temesgen, M.; Rockström, J. The Role of Water Harvesting to Achieve Sustainable Agricultural Intensification and Resilience against Water Related Shocks in Sub-Saharan Africa. Agric. Ecosyst. Environ. 2013, 181, 69-79. [CrossRef]

134. Mourad, K.A.; Yimer, S.M. Socio-Economic Potential of Rainwater Harvesting in Ethiopia. Sustain. Agric. Res. 2016, 6, 73. [CrossRef]

135. Teshome, A.; Adgo, E.; Mati, B. Impact of Water Harvesting Ponds on Household Incomes and Rural Livelihoods in Minjar Shenkora District of Ethiopia. Ecohydrol. Hydrobiol. 2010, 10, 315-322. [CrossRef] 
136. Gebremeskel, G.; Gebremicael, T.G.; Girmay, A. Economic and Environmental Rehabilitation through Soil and Water Conservation, the Case of Tigray in Northern Ethiopia. J. Arid Environ. 2018, 151, 113-124. [CrossRef]

137. Adela, F.A.; Aurbacher, J.; Abebe, G.K. Small-Scale Irrigation Scheme Governance-Poverty Nexus: Evidence from Ethiopia. Food Sec. 2019, 11, 897-913. [CrossRef]

138. Bacha, D.; Namara, R.; Bogale, A.; Tesfaye, A. Impact of Small-Scale Irrigation on Household Poverty: Empirical Evidence from the Ambo District in Ethiopia. Irrig. Drain. 2011, 60, 1-10. [CrossRef]

139. Adugna, E.; Ermias, A.; Mekonnen, A.; Mihret, D. The Role of Small Scale Irrigation in Poverty Reduction. J. Dev. Agric. Econ. 2014, 6, 12-21. [CrossRef]

140. Haile, G.G. Irrigation in Ethiopia, a Review. Acad. J. Agric. Res. 2015, 3, 264-269.

141. Asrat, D.; Anteneh, A.; Yildiz, F. The Determinants of Irrigation Participation and Its Impact on the Pastoralist and AgroPastoralists Income in Ethiopia: A Review Study. Cogent Food Agric. 2019, 5, 1679700. [CrossRef]

142. You, L.; Ringler, C.; Wood-Sichra, U.; Robertson, R.; Wood, S.; Zhu, T.; Nelson, G.; Guo, Z.; Sun, Y. What Is the Irrigation Potential for Africa? A Combined Biophysical and Socioeconomic Approach. Food Policy 2011, 36, 770-782. [CrossRef]

143. Amede, T. Technical and Institutional Attributes Constraining the Performance of Small-Scale Irrigation in Ethiopia. Water Resour. Rural Dev. 2015, 6, 78-91. [CrossRef]

144. Tadesse, A.; Gebrelibanos, T.; Geberehiwot, M. Characterization and Impact Assessment of Water Harvesting Techniques: A Case Study of Abreha Weatsbeha Watershed, Tigray, Ethiopia. 2016, pp. 1-28. Available online: https://www.saide.org.za/resources/ AgshareII/Water\%20Harvesting\%20Systems\%20Case\%20Study\%20Final.pdf (accessed on 15 October 2020).

145. Alemu, M.M. Indigenous Agroforestry Practices in Southern Ethiopia: The Case of Lante, Arba Minch. Open Access Libr. J. 2016, 3. [CrossRef]

146. Mucheru-Muna, M.; Pypers, P.; Mugendi, D.; Kung'u, J.; Mugwe, J.; Merckx, R.; Vanlauwe, B. A Staggered Maize-Legume Intercrop Arrangement Robustly Increases Crop Yields and Economic Returns in the Highlands of Central Kenya. Field Crop. Res. 2010, 115, 132-139. [CrossRef]

147. Wato, T.; Amare, M. Opportunities and Challenges of Scaling up Agroforestry Practices in Sub-Saharan Africa: A Review. AG 2020, 41. [CrossRef]

148. Hassan, M.; Hadgu, K.; Birhane, E.; Muthuri, C.; Sinclair, F.; Mowo, J.; Mwangi, A. Agroforestry in Ethiopia: Using Trees on Farms to Boost Crop. Productivity and Strengthen Food Security; ICRAF Policy Brief No. 30; World Agroforestry Center India: New Delhi, India, 2016.

149. Meragiaw, M. Role of Agroforestry and Plantation on Climate Change Mitigation and Carbon Sequestration in Ethiopia. J. Tree Sci. 2017, 36, 1. [CrossRef]

150. Kassie, G.W. Agroforestry and Land Productivity: Evidence from Rural Ethiopia. Cogent Food Agric. 2016, 2. [CrossRef]

151. Gelaw, A.; Singh, B.R.; Lal, R. Soil Organic Carbon and Total Nitrogen Stocks under Different Land Uses in a Semi-Arid Watershed in Tigray, Northern Ethiopia. Agric. Ecosyst. Environ. 2014, 188, 256-263. [CrossRef]

152. Negash, M.; Starr, M. Biomass and Soil Carbon Stocks of Indigenous Agroforestry Systems on the South-Eastern Rift Valley Escarpment, Ethiopia. Plant. Soil 2015, 393, 95-107. [CrossRef]

153. Duriaux-Chavarría, J.-Y.; Baudron, F.; Gergel, S.E.; Yang, K.F.; Eddy, I.M.S.; Sunderland, T. More People, More Trees: A Reversal of Deforestation Trends in Southern Ethiopia. Land Degrad. Dev. 2021, 32, 1440-1451. [CrossRef]

154. Duriaux Chavarría, J.-Y.; Baudron, F.; Sunderland, T. Retaining Forests within Agricultural Landscapes as a Pathway to Sustainable Intensification: Evidence from Southern Ethiopia. Agric. Ecosyst. Environ. 2018, 263, 41-52. [CrossRef]

155. Baudron, F.; Duriaux Chavarría, J.-Y.; Remans, R.; Yang, K.; Sunderland, T. Indirect Contributions of Forests to Dietary Diversity in Southern Ethiopia. Ecol. Soc. 2017, 22. [CrossRef]

156. Ango, T.G.; Börjeson, L.; Senbeta, F.; Hylander, K. Balancing Ecosystem Services and Disservices: Smallholder Farmers' Use and Management of Forest and Trees in an Agricultural Landscape in Southwestern Ethiopia. Ecol. Soc. 2014, 19. [CrossRef]

157. Onyekwelu, J.C.; Olusola, J.A.; Stimm, B.; Mosandl, R.; Agbelade, A.D. Farm-Level Tree Growth Characteristics, Fruit Phenotypic Variation and Market Potential Assessment of Three Socio-Economically Important Forest Fruit Tree Species. For. Trees Livelihoods 2015, 24, 27-42. [CrossRef]

158. Bishaw, B.; Neufeldt, H.; Mowo, J.; Abdelkadir, A.; Muriuki, J.; Dalle, G.; Assefa, T.; Guillozet, K.; Kassa, H.; Dawson, I.K.; et al. Farmers' Strategies for Adapting to and Mitigating Climate Variability and Change through Agroforestry in Ethiopia and Kenya. p. 96. Available online: https://www.worldagroforestry.org/publication/farmers-strategies-adapting-and-mitigating-climatevariability-and-change-through (accessed on 25 September 2020).

159. Harvey, C.A.; Chacón, M.; Donatti, C.I.; Garen, E.; Hannah, L.; Andrade, A.; Bede, L.; Brown, D.; Calle, A.; Chará, J.; et al. Climate-Smart Landscapes: Opportunities and Challenges for Integrating Adaptation and Mitigation in Tropical Agriculture. Conserv. Lett. 2014, 7, 77-90. [CrossRef]

160. Josephson, A.L.; Ricker-Gilbert, J.; Florax, R.J.G.M. How Does Population Density Influence Agricultural Intensification and Productivity? Evidence from Ethiopia. Food Policy 2014, 48, 142-152. [CrossRef]

161. Ellis-Jones, J.; Mekonnen, K.; Gebreselassie, S.; Schulz, S. Challenges and Opportunities to the Intensification of Farming Systems in the Highlands of Ethiopia: Results of a Participatory Community Analysis; International Livestock Research Institute: Addis Ababa, Ethiopia, 2013. 
162. Nigussie, A.; Kuyper, T.W.; Neergaard, A. de Agricultural Waste Utilisation Strategies and Demand for Urban Waste Compost: Evidence from Smallholder Farmers in Ethiopia. Waste Manag. 2015, 44, 82-93. [CrossRef]

163. Zeng, D.; Alwang, J.; Norton, G.; Jaleta, M.; Shiferaw, B.; Yirga, C. Land Ownership and Technology Adoption Revisited: Improved Maize Varieties in Ethiopia. Land Use Policy 2018, 72, 270-279. [CrossRef] [PubMed]

164. Gebremedhin, B.; Swinton, S.M. Investment in Soil Conservation in Northern Ethiopia: The Role of Land Tenure Security and Public Programs. Agric. Econ. 2003, 29, 69-84. [CrossRef]

165. Deressa, T.T. Factors Affecting the Choices of Coping Strategies for Climate Extremes: The case of farmers in the Nile Basin of Ethiopia; IFPRI Discussion Paper, 1032; International Food Policy Research Institute (IFPRI): Washington, DC, USA, $2010 ;$ p. 36.

166. Zerga, B.; Gebeyehu, G. Climate Change in Ethiopia Variability, Impact, Mitigation, and Adaptation. J. Soc. Sci. Humanit. Res. 2016, 2, 66-84.

167. Kassie, M.; Zikhali, P.; Pender, J.; Köhlin, G. The Economics of Sustainable Land Management Practices in the Ethiopian Highlands: Economics of Sustainable Land Management Practices. J. Agric. Econ. 2010, 61, 605-627. [CrossRef]

168. Belay, A.; Recha, J.W.; Woldeamanuel, T.; Morton, J.F. Smallholder Farmers' Adaptation to Climate Change and Determinants of Their Adaptation Decisions in the Central Rift Valley of Ethiopia. Agric. Food Secur. 2017, 6, 24. [CrossRef]

169. Zerssa, G.W.; Feyssa, D.H. Natural Resource Use Conflicts: Gender Opportunities and Constraints in Conflict Management: A Review. J. Biol. Chem. Res. 2016, 33, 12.

170. Sibanda, L.M.; Mwamakamba, S.N.; Mentz, M.; Mthunzi, T. Policies and Practices for Climate-Smart Agriculture in Sub-Saharan Africa: A Comparative Assessment of Challenges and Opportunities across 15 Countries; Food, Agriculture and Natural Resources Policy Analysis Network (FANRPAN): Pretoria, South Africa, 2017.

171. Wakeyo, M.; Gardebroek, C. Share of Irrigated Land and Farm Size in Rainwater Harvesting Irrigation in Ethiopia. J. Arid Environ. 2017, 139, 85-94. [CrossRef]

172. Branca, G.; Tennigkeit, T.; Mann, W.; Lipper, L. Identifying Opportunities for Climate-Smart Agriculture Investments in Africa; Food and Agriculture Organization of the United Nations: Rome, Italy, 2012; p. 102.

173. Deresse, M.; Zerihun, A. Financing Challenges of Smallholder Farmers: A Study on Members of Agricultural Cooperatives in Southwest Oromia Region, Ethiopia. Afr. J. Bus. Manag. 2018, 12, 285-293. [CrossRef]

174. Gebreselassie, S.; Kirui, O.K.; Mirzabaev, A. Economics of Land Degradation and Improvement in Ethiopia. In Economics of Land Degradation and Improvement-A Global Assessment for Sustainable Development; Nkonya, E., Mirzabaev, A., von Braun, J., Eds.; Springer International Publishing: Cham, Switzerland, 2016; pp. 401-430. ISBN 978-3-319-19167-6.

175. Howell, J. Chapter 6 Rural Electrification and Renewable Energy in Ethiopia. In Environmental Policy Review 2011: Rural Electrification \& RenewableEnergy in Ethiopia; The Environmental Policy Group in the Environmental Studies Program at Colby College: Waterville, ME, USA, 2011; p. 129.

176. Guta, D.D. Assessment of Biomass Fuel Resource Potential And Utilization in Ethiopia: Sourcing Strategies for Renewable Energies. Int. J. Renew. Energy Res. 2012, 2, 9.

177. Bekele, K.; Hager, H.; Mekonnen, K. Woody and non-woody biomass utilisation for fuel and implications on plant nutrients availability in the Mukehantuta watershed in Ethiopia. Afr. Crop. Sci. J. 2013, 21, 625-636.

178. Dresen, E.; DeVries, B.; Herold, M.; Verchot, L.; Müller, R. Fuelwood Savings and Carbon Emission Reductions by the Use of Improved Cooking Stoves in an Afromontane Forest, Ethiopia. Land 2014, 3, 1137-1157. [CrossRef]

179. Gizachew, B.; Tolera, M. Adoption and Kitchen Performance Test of Improved Cook Stove in the Bale Eco-Region of Ethiopia. Energy Sustain. Dev. 2018, 45, 186-189. [CrossRef]

180. Fikadu Lemma, B.; Woldeamanuel, T. Emissions and Fuel Use Performance of Two Improved Stoves and Determinants of Their Adoption in Dodola, Southeastern Ethiopia. Sustain. Environ. Res. 2018, 28, 32-38. [CrossRef]

181. Tefera, T. Determinants of Coffee Husk Manure Adoption: A Case Study from Southern Ethiopia. Indian J. Agric. Econ. 2010, 65, $1-14$.

182. Shemekite, F.; Gómez-Brandón, M.; Franke-Whittle, I.H.; Praehauser, B.; Insam, H.; Assefa, F. Coffee Husk Composting: An Investigation of the Process Using Molecular and Non-Molecular Tools. Waste Manag. 2014, 34, 642-652. [CrossRef] [PubMed]

183. Rameshwar, M.Y.; Argaw, A. Manurial Value of Khat Waste Vermicompost from Awday, Harar Town, Ethiopia. Int J. Recycl Org. Waste Agric. 2016, 5, 105-111. [CrossRef]

184. Gezahegn, D.; Seyoum, M.; Jorge, D. Vermicomposting as a Sustainable Practice to Manage Coffee Husk, Enset Waste (Ensetverticosum), Khat Waste (Catha Edulis) and Vegetable Waste Amended with Cow Dung Using an Epigeic Earthworm Eiseniaandrei (Bouch' 1972). Int. J. Pharm Tech. Res. 2012, 4, 15-24.

185. Bekele, A.; Kibret, K.; Bedadi, B.; Yli-Halla, M.; Balemi, T. Effects of Lime, Vermicompost, and Chemical P Fertilizer on Selected Properties of Acid Soils of Ebantu District, Western Highlands of Ethiopia. Appl. Environ. Soil Sci. 2018, 2018, 1-13. [CrossRef]

186. Gebrehiwot, K.A. A Review on Waterlogging, Salinization and Drainage in Ethiopian Irrigated Agriculture. Sustain. Water Resour. Manag. 2018, 4, 55-62. [CrossRef]

187. Qureshi, A.S.; Mohammed, M.; Daba, A.W.; Hailu, B.; Belay, G.; Tesfaye, A.; Ertebo, T.M. Improving Agricultural Productivity on Salt-Affected Soils in Ethiopia: Farmers' Perceptions and Proposals. Afr. J. Agric. Res. 2019, 14, 897-906.

188. Kidia, K.G. Salinity Prediction and Mitigation Measures to Reduce Soil Salinity on Irrigated Land in Awash Basin, Ethiopia; Institute of Hydraulics and Rural Water Management: Vienna, Austria, 2019. [CrossRef] 
189. Erkossa, T.; Gizaw, A.; Stahr, K. Land Preparation Methods Efficiency on the Highland Vertisols of Ethiopia. Irrig. Drain. 2004, 53, 69-75. [CrossRef]

190. Saguye, T.S. Determinants of Adoption of Sustainable Land Management (SLM) Practices among Smallholder Farmers' in Jeldu District, West Shewa Zone, Oromia Region, Ethiopia. Glob. J. Sci. Front. Res. H Environ. Earth Sci. 2017, 17, 111-127.

191. Munroe, J.W.; Isaac, M.E. N2-Fixing Trees and the Transfer of Fixed-N for Sustainable Agroforestry: A Review. Agron. Sustain. Dev. 2014, 34, 417-427. [CrossRef]

192. Reed, J.; van Vianen, J.; Foli, S.; Clendenning, J.; Yang, K.; MacDonald, M.; Petrokofsky, G.; Padoch, C.; Sunderland, T. Trees for Life: The Ecosystem Service Contribution of Trees to Food Production and Livelihoods in the Tropics. For. Policy Econ. 2017, 84, 62-71. [CrossRef]

193. Woldegiorgis, B. A History and Policy Analyses of Forest Governance in Ethiopia and REDD+. Master's Thesis, Uppsala Universitet, Uppsala, Sweden, 2020. [CrossRef]

194. Getahun, E. Ethiopia to Grow 5 Billion Trees in the Second Green Legacy Campaign. 2020. Available online: https://www.cgiar. org/news-events/news/ethiopia-to-grow-5-billion-trees-in-the-second-green-legacy-campaign/ (accessed on 2 January 2021)

195. Tura, E.G.; Kenea, T.; Kaso, T. Determinants of Demand for Credit among Wheat and Teff Smallholder Farmers in Central of Ethiopia (Arsi and South West Shewa). Am. Res. J. Bus. Manag. 2017, 3. [CrossRef]

196. Eshetu, Z.; Simane, B.; Tebeje, G.; Negatu, W. Climate Finance in Ethiopia; Overseas Development Institute: London, UK; Climate Science Centre: Addis Ababa, Ethiopia, 2014; p. 113.

197. Bartlett, A. No More Adoption Rates! Looking for Empowerment in Agricultural Development Programmes. Dev. Pract. 2008, 18, 524-538. [CrossRef]

198. Tsige, M. Who Benefits from Production Outcomes? Gendered Production Relations among Climate-Smart Agriculture Technology Users in Rural Ethiopia. Rural Sociol. 2019, 84, 799-825. [CrossRef]

199. Bartlett, A. Entry Points for Empowerment; CARE's Rural Livelihoods Programme (RLP); CARE: Mohakhali, Dhaka, Bangladesh, 2004.

200. Hariharan, V.K.; Mittal, S.; Rai, M.; Agarwal, T.; Kalvaniya, K.C.; Stirling, C.M.; Jat, M.L. Does Climate-Smart Village Approach Influence Gender Equality in Farming Households? A Case of Two Contrasting Ecologies in India. Clim. Chang. 2020, 158, 77-90. [CrossRef]

201. Ashango, A.; Mesene, M. Clean Development Mechanisms (CDM) and Climate Smart Agriculture (CSA): Role and Implication for Sustainable Natural Resource Management: Ethiopian Context. Civ. Environ. Res. 2019, 11, 27-40.

202. Haile, T. G Comparative Analysis for the SDPRP, PASDEP and GTP of the FDR of Ethiopia. Glob. J. Bus. Econ. Manag. 2015, 5, 13-24. [CrossRef]

203. Dube, A.K.; Fawole, W.O.; Govindasamy, R.; Ozkan, B. Agricultural development led industrialization in Ethiopia: Structural break analysis. Int. J. Agric. For. Life Sci. 2019, 3, 193-201.

204. Woolf, D.; Solomon, D.; Lehmann, J. Land Restoration in Food Security Programmes: Synergies with Climate Change Mitigation. Clim. Policy 2018, 18, 1260-1270. [CrossRef]

205. Negra, C. Integrated National Policy Approaches to Climate-Smart Agriculture; CGIAR Research Program on Climate Change, Agriculture and Food Security (CCAFS): Copenhagen, Denmark, 2014; p. 32.

206. Federal Democratic Republic of Ethiopia. Forest Development, Conservation, and Utilization Proclamation; Proclamation No 1065/2018; FDRE: Addis Ababa, Ethiopia, 2018.

207. Rebecca, M.; Habtemariam, K.; Steven, L.; Belay, Y. Fostering Tenure Security for Forest Landscape Restoration in Ethiopia: Creating Enabling Conditions for the 2018 Forest Proclamation; Center for International Forestry Research (CIFOR): Bogor Indonesia, 2019. 